OPEN ACCESS

Edited by: Manfred B. Lutz,

Julius Maximilian University of Würzburg, Germany

Reviewed by:

Nobuyuki Onai,

Kanazawa Medical University, Japan Alexander Steinkasserer

University Hospital Erlangen, Germany

*Correspondence:

Daniele V. F. Tauriello

Daniele.Tauriello@radboudumc.nl

${ }^{\dagger}$ These authors share senior authorship

Specialty section: This article was submitted to Antigen Presenting Cell Biology,

a section of the journal

Frontiers in Immunology

Received: 14 June 2021 Accepted: 14 September 2021

Published: 06 October 2021

Citation:

Subtil B, Cambi A, Tauriello DVF and de Vries IJM (2021) The

Therapeutic Potential of Tackling Tumor-Induced Dendritic Cell Dysfunction in Colorectal Cancer.

Front. Immunol. 12:724883. doi: 10.3389/fimmu.2021.724883

\section{The Therapeutic Potential of Tackling Tumor-Induced Dendritic Cell Dysfunction in Colorectal Cancer}

\author{
Beatriz Subtil ${ }^{1}$, Alessandra Cambi ${ }^{1}$, Daniele V. F. Tauriello ${ }^{1 * t}$ and I. Jolanda M. de Vries ${ }^{2 \dagger}$ \\ ${ }^{1}$ Department of Cell Biology, Radboud Institute for Molecular Life Sciences, Radboud University Medical Center, Nijmegen, \\ Netherlands, ${ }^{2}$ Department of Tumor Immunology, Radboud Institute for Molecular Life Sciences, Radboud University \\ Medical Center, Nijmegen, Netherlands
}

Colorectal cancer (CRC) is the third most diagnosed malignancy and the second leading cause of cancer-related deaths worldwide. Locally advanced and metastatic disease exhibit resistance to therapy and are prone to recurrence. Despite significant advances in standard of care and targeted (immuno)therapies, the treatment effects in metastatic CRC patients have been modest. Untreatable cancer metastasis accounts for poor prognosis and most CRC deaths. The generation of a strong immunosuppressive tumor microenvironment (TME) by CRC constitutes a major hurdle for tumor clearance by the immune system. Dendritic cells (DCs), often impaired in the TME, play a critical role in the initiation and amplification of anti-tumor immune responses. Evidence suggests that tumor-mediated DC dysfunction is decisive for tumor growth and metastasis initiation, as well as for the success of immunotherapies. Unravelling and understanding the complex crosstalk between CRC and DCs holds promise for identifying key mechanisms involved in tumor progression and spread that can be exploited for therapy. The main goal of this review is to provide an overview of the current knowledge on the impact of CRC-driven immunosuppression on DCs phenotype and functionality, and its significance for disease progression, patient prognosis, and treatment response. Moreover, present knowledge gaps will be highlighted as promising opportunities to further understand and therapeutically target DC dysfunction in CRC. Given the complexity and heterogeneity of $\mathrm{CRC}$, future research will benefit from the use of patient-derived material and the development of in vitro organoid-based co-culture systems to model and study DCs within the CRC TME.

Keywords: metastatic colorectal cancer, cancer immunity, dendritic cell defects, immunotherapy, tumor microenvironment, immunosuppression, patient-derived organoids

\section{INTRODUCTION}

Colorectal cancer (CRC) is one of the most common and deadliest cancers worldwide (1,2). At early stages of localized disease, surgical resection leads to a good prognosis or even cure (3). Unfortunately, more than half of the CRC patients develop metastasis, either at the time of diagnosis or later as relapse (4). The most common metastatic site is the liver, but metastasis can 
also be found in the lungs, peritoneum, bones, and brain. Distant metastases are increasingly resected with curative intent $(5,6)$. For unresectable or recurrent metastatic disease, standard chemotherapies, as well as targeted treatments, have improved median overall survival to over 30 months (7-9). Despite these significant advances, metastatic CRC (mCRC) patients remain largely unresponsive to (immuno)therapy resulting in a 5-year survival rate of only $12 \%$ (1). At the moment, different therapeutic approaches are being actively investigated to fulfil the unmet need for therapies in $\operatorname{mCRC}(10,11)$.

As with most cancers, CRC develops and spreads by evading immunosurveillance. To subvert the immune system, tumors evolved a number of escape mechanisms including loss of tumor antigens, upregulation of inhibitory molecules, and the generation of an immunosuppressive environment which recruits and corrupts stromal and immune cells (12). The CRC tumor microenvironment (TME) prevents immunosurveillance, supporting tumor growth and progression $(13,14)$. Besides hampering anti-tumor immunity, the generation of an immunosuppressive environment also hinders the success of immunotherapies $(10,14)$.

Dendritic cells (DCs), also known as professional antigen presenting cells, are a key immune cell type often impaired by the immunosuppressive TME. DCs are the central players in triggering, coordinating and amplifying anti-tumor immune responses, and in driving the clinical success of immunotherapies (15-17). However, in the presence of immunosuppressive signals, such as the ones released by tumor cells, DCs become dysfunctional and induce tolerance. Several studies suggest that tumor-mediated impairment of DC functions is decisive for immune evasion, tumor growth, metastasis initiation, and treatment resistance in different cancers including CRC (17-23). Despite the key role of functional DCs in anti-tumor immunity and treatment response, it is still largely unclear how CRC shapes DC fate.

The main aim of this review is to provide an overview of the current knowledge on how primary and metastatic CRC-driven immunosuppression affects DC phenotype and functionality. We will assess how this correlates with disease progression, mCRC patients' prognosis and treatment response. Moreover, the potential of therapies to revert DC defects in CRC will be discussed. From there, knowledge gaps will be pinpointed as unexplored avenues to study and target DC dysfunction in CRC.

\section{COLORECTAL CANCER}

CRC comprises a highly complex, heterogenous, and lethal group of diseases. Several factors contribute to CRC development and have implications in treatment response. As mentioned, the survival and treatment options of CRC patients largely depend on the stage, i.e., the extent of tumor invasion and spread at the time of diagnosis. Outgrowth of metastasis is facilitated by synchronous undetectable disseminated metastatic cells, tumor shedding into circulation, and therapyinduced immune impairment. As such, early detection of CRC through screening becomes a crucial factor to reduce mortality of the disease. However, disease stage is not always predictive for patient response and outcome. CRC patients at the same stage might have different disease progression based on the molecular heterogeneity of the tumor and the composition of the TME (24-27).

\section{Tumorigenesis}

CRC develops from a multistep accumulation of genetic and epigenetic alterations (28). The majority of CRC cases arise from sporadic mutations due to an interplay of environmental and lifestyle factors, the remaining due to genetic predisposition (29, 30). CRC develops from abnormal proliferation of mucosal epithelial cells of the large intestine, named polyps or adenomas, which can evolve to adenocarcinomas. CRC can develop from adenoma to carcinoma through one or a combination of different molecular mechanisms, namely chromosomal instability, CpG island methylation, and DNA mismatch-repair deficiency (24). Different sequential driver mutations associated with tumorigenesis occur in the APC/ $\beta$ catenin, KRAS, MAPK and BMP/TGF- $\beta$ pathways, as well as in tumor suppressor genes, such as TP53, at later stages $(31,32)$. As mutations accumulate, adenocarcinomas become invasive and spread to distant sites in the body establishing metastasis.

Depending on the underlying driving mechanism of genomic instability, CRC tumors can be broadly classified into (1) microsatellite instability-high (MSI-H), which account for $\sim 15 \%$ of tumors and (2) microsatellite stable (MSS) accounting for the remaining $\sim 85 \%$ of the cases (33). MSI tumors are characterized by high frequency of replication errors due to defective DNA mismatch repair mechanisms, which lead to a hypermutated state. Typically, MSI tumors are highly immunogenic, present high percentage of immune infiltrates, and are associated with a more favorable prognosis (34). In contrast, MSS tumors, which account for the large majority of CRC cases, are poorly immunogenic with low mutational burden, and are linked to poor prognosis $(31,32)$.

In mCRC, treatment with immune checkpoint inhibitors presents promising responses only in a minority of patients, with MSI tumors, while MSS tumors do not respond to PD-1 or PD-L1 inhibitors $(35,36)$. Unresponsiveness of MSS tumors to immune checkpoint inhibition and other immunotherapies has been associated with the low number of tumor-specific neoantigens, lack of infiltrating immune cells, and tumormediated immunosuppression (37). This implies that, to date, the vast majority of mCRC patients does not qualify for immunotherapy.

Besides MSS/MSI stratification, a more comprehensive classification system for CRC has been developed. The Consensus Molecular Subtype system, which divides CRC patients in 4 subtypes based on transcriptome analysis of the tumor and associated stromal and immune cells $(38,39)$. This stratification system suggests that characterizing gene expression of not only tumor cells but also of surrounding tumor-associated cells (such as fibroblasts, leukocytes and endothelial cells) allows better stratification of patients and confers higher predictive value for prognosis, management, and selection of appropriate 
treatment (40). This emphasizes the importance of studying both the tumor and its surroundings.

\section{The Tumor (Immune) Microenvironment}

CRC initiation, progression, metastatic dissemination, and treatment resistance is not only driven by the accumulation of genomic and epigenomic aberrations but also by intricate and dynamic interactions between malignant and neighboring cells in the TME (41-44). Surrounding cells comprise endothelial cells, gut microbiota, cancer-associated fibroblasts (CAFs), and immune cells including tumor-associated macrophages (TAMs), myeloid-derived suppressor cells (MDSCs), natural killer (NK) cells, DCs, and T cells (45). Tumor cells are well-known for having a strong modulatory effect, for being able to recruit, corrupt or re-educate surrounding cells towards tumorpromoting phenotypes that foster tumor growth and spread.

Importantly, CRC generates a strong immunosuppressive TME that hampers immunosurveillance and allows immune evasion. To escape eradication by the immune system CRC recruits and polarizes immunosuppressive regulatory $\mathrm{T}$ cells (Tregs), TAMs, and MDSCs. In addition, CRC inhibits or excludes immune cells with anti-tumor potential such as DCs, NK cells, and effector T cells from the TME. By regulating local and systemic immune function, CRC creates immune impairments and an environment propitious for tumor growth and dissemination (46). Several studies have reported that $\mathrm{CRC}$-induced local and systemic immune dysfunctions are closely associated with patient prognosis and sensitivity to therapy (47-51).

The intricate web of interactions within the TME is mediated by cell-to-cell contact and soluble factors, such as cytokines, chemokines, and growth factors, derived from the tumor and activated surrounding cells. These factors are constantly remodeling the TME and have not only local but also systemic effects, which are crucial for generalized immunosuppression enabling the generation of pre-metastatic niches and successful metastatic establishment (52).

One key immunosuppressive signaling molecule associated with CRC is transforming growth factor- $\beta$ (TGF- $\beta$ ). High TGF- $\beta$ expression in the TME of CRC has been linked to poor prognosis with a crucial role in successful tumor progression and metastasis development (40, 53-59). TGF- $\beta$ modifies the TME by regulating infiltration and by suppressing or tweaking the phenotype of immune cells towards tolerance, impeding anti-tumor immunity $(53,60,61)$. Consistent with these findings, neutralization of TGF- $\beta$ signaling in the TME was found to impair liver metastasis establishment by unleashing $\mathrm{T}$ cell and NK cells anti-tumor responses, in different pre-clinical CRC models (14, 40, 54, 55, 58, 62). Promisingly, in a metastatic mouse model for CRC, treatment of established metastasis with anti-PD-L1 antibodies in combination with TGF- $\beta$ blockade resulted in potent curative anti-tumor $\mathrm{T}$ cell-mediated immune responses (14). Besides TGF- $\beta$, other factors such as IL-6, IL-33, IL-8, IL-23, PGE2 and IDO-1 have shown similar immunomodulatory properties and impact in metastasis development and patient prognosis in CRC (63-74). These studies highlight the role and the potential of further exploring the interactions between malignant cells and immune cells, and combining current therapies with agents designed to target the TME $(10,13)$.

It is clear that regulation of immune cells by the immunosuppressive TME generated by CRC has a pivotal role in disease progression, not only by hampering immuno-surveillance but also by compromising the effectiveness of immunotherapies. Since, no effective treatment is available for the majority of mCRC patients, it becomes imperative to further understand how CRC interferes with immune activation for identification of new mechanisms for complementary therapies. DCs, as the main orchestrators of innate and adaptive anti-cancer immunity, appear as promising targets to unleash immune responses and immunotherapy efficacy.

\section{DENDRITIC CELLS: THE HUB OF ANTI-TUMOR IMMUNITY}

DCs comprise a heterogenous population of cells specialized in antigen capture, processing, and presentation. DCs act as hub of the immune system by initiating, linking and coordinating innate and adaptive immune responses $(15,16)$. DCs are key regulators of specific immune response owing to their unique capacity to (cross-)present antigens and prime T cells $(15,20)$. In anti-tumor immunity, DCs can promote T cell and NK cytotoxic activities, and also exert direct tumoricidal activity, sustaining cancer immunosurveillance. Consequently, DCs have been shown to have a crucial role in inhibiting local tumor growth, tumor dissemination, and metastatic establishment (17).

Tissue-resident DCs in steady-state conditions scan the environment for antigens and danger signals, acting as sentinels. In homeostatic conditions or under suppressive environmental cues, DCs present an immature and tolerogenic phenotype, characterized by low expression of co-stimulatory molecules and pro-inflammatory cytokines, inability to prime $\mathrm{T}$ cells, and secretion of immunosuppressive cytokines (e.g., IL-10 and TGF $\beta$ ). This functional state ensures immune (self-) tolerance, through various mechanisms including $\mathrm{T}$ cell depletion and anergy, as well as generation of Tregs (15, 75-77).

If uptake and processing of (tumor) antigens occurs in the presence of danger signals and inflammatory cytokines, DCs undergo maturation (78). The maturation process encompasses several morphological, functional, and phenotypical changes, which include enhanced migration abilities through CCR7 expression, upregulation of co-stimulatory molecules CD80, CD83, and CD86, and secretion of pro-inflammatory cytokines such as IL-12, IL-6, TNF- $\alpha$ and IL1- $\beta$. All these signals, together with antigen presentation on major histocompatibility complexes (MHC), are required for proper priming, activation, and proliferation of $\mathrm{T}$ cells, and induction of an antigen-specific response $(15,75,76)$. Upon maturation, DCs migrate to a lymph node, where they prime and activate antigen/tumor-specific $\mathrm{T}$ cells. Subsequently, T helper (Th) or cytotoxic T cells (CTL), migrate into the tumor site where they can perform their effector functions $(15,79)$. 
Additionally, tumor-infiltrating DCs (TIDCs) have been reported to regulate the magnitude and duration of $\mathrm{T}$ cell responses within the TME, either through direct antigen presentation or establishment of a favorable cytokine environment, in different tumor models including breast cancer and melanoma (15,20,79-84). Antigen presentation within tumors might occur in ectopic tertiary lymphoid structures (TLS), which are hypothesized to play an important role in response to neoantigens that form during later stages of tumor progression (15). It seems that in the cancer setting, tumor-draining lymph node DCs might initially prime naïve $\mathrm{T}$ cells, while later intra-tumoral DCs further license and activate T cells in the tumor bed (85). Overall, these studies indicate that TIDCs are required for recruitment, re-priming, and re-stimulation of $\mathrm{T}$ cells to acquire full effector function in the TME (20).

DCs have an additional role in innate anti-tumor immunity, through modulation and enhancement of NK cell activity. On the one hand, mature DCs potentiate NK cytotoxicity against tumor cells by secreting pro-inflammatory cytokines (e.g., IL-12, IL15) and cell-to-cell contact. On the other hand, NK cells promote DC infiltration into tumors, as well as their maturation, cytokine-producing ability, migratory potential, and facilitate cross-presentation through the secretion of chemokines and growth factors such as CCL5, XCL1, and FLT3L. This interaction in turn results in enhanced and stronger anti-tumor $\mathrm{T}$ cell activation. The dynamic crosstalk between DC and NK takes place in both tumor-draining lymph nodes and in the TME $(74,86,87)$. In fact, an optimal anti-tumor immune response appears to rely on effector T cells and NK cells, which are jointly induced and coordinated by DCs (86). DCs are thus essential mediators for the induction of powerful immune responses against cancer cells (88).

Notably, DCs encompass a highly complex and heterogenous population. Regarding their origin and differentiation pathway, four major lineages can be defined: myeloid or conventional DCs (cDC1 and $\mathrm{cDC} 2$ ), plasmacytoid DCs (pDC), inflammatory or monocyte-derived DCs (MoDC), and Langerhans cells (LC). Even though all DCs harbor antigen-presenting and $\mathrm{T}$ cell activating abilities, the different subsets present distinct phenotypes and specialized functions. This expands the range and flexibility of immune responses $(21,73,89)$. For instance, cDC1 are specialized in cross-presentation and CD8+ T cell responses, cDC2 in $\mathrm{CD} 4+\mathrm{T}$ cell priming, $\mathrm{pDCs}$ in type $\mathrm{I}$ interferon-mediated responses, and MoDCs perform different functions in inflammatory settings (15, 21, 89-93).

As such, the immunogenic or tolerogenic functions of DCs, T cell priming or tolerance, depend on their functional subset and their maturation status, which is dictated by environmental cues $(75,77,79,88,94)$. The phenotypic and functional plasticity of DCs renders them susceptible targets for the evolution of tumormediated suppressive mechanisms (95).

\section{TUMOR-INDUCED DC DYSFUNCTION}

DCs can play either a regulatory, tolerogenic function or coordinate potent immune responses, depending on the local tumor milieu. Tumors take advantage of this functional plasticity by interfering with DC functions and shifting the balance towards immune evasion (22). As such, tumors employ a variety of mechanisms to disrupt DC functions, mainly mediated through the immunosuppressive TME, that compromise the development of anti-tumor immune responses and facilitate local and metastatic progression (79).

Quantitative and functional impairments of circulating and intra-tumoral DCs have been widely observed in several types of malignancies including melanoma, breast, pancreatic, ovarian, colorectal, prostate, and lung cancer (16). Several studies, have elucidated on escape mechanisms employed by tumors to disrupt DC functions at different levels (Figure 1):

1) Impairing proper differentiation of DCs from hematopoietic and myeloid precursors leading to decreased local and circulating DC numbers. Instead, tumors favor differentiation of precursors into immunosuppressive populations, such as MDSCs, TAMs, and BDCA1+CD14+ cells, which further contribute to an immunosuppressive environment (23, 73, 96-104). 2) Inducing apoptosis or favoring exclusion of mature DCs from the TME, for instance, by blocking NKmediated recruitment of DCs $(74,105)$. Furthermore, inhibiting proper DC maturation and activation, preventing expression of co-stimulatory molecules, and secretion of pro-inflammatory cytokines, blocking DCs at an immature state. Several tumorderived factors have been shown to mediate DC defects including TGF- $\beta$, TNF- $\alpha$, IDO-1, PGE2, IL-6, IL-10, VEGF, and GM-CSF (70, 106-116). These factors hinder DC migration, antigen presentation, and effective T cell and NK activation (105-108, 113, 116-128). 3) Directly and indirectly inhibiting anti-tumor T cell functions. The TME skews DCs from immunostimulatory into tolerogenic and immunosuppressive phenotypes and functions, affecting $\mathrm{T}$ cell survival and proliferation, or by inducing anergy (an hyporesponsive state) and the expansion of Treg cells. These processes are characterized by the increased expression of immunosuppressive factors such as TGF- $\beta$, IL-10, PGE2, IDO-1, and PD-L1 by DCs (104, 114, 115, 129-142).

Overall, the presence of an immunosuppressive TME induces DC-mediated tolerance rather than immunity, contributing to immune escape and dampening of anti-tumor $\mathrm{T}$ cell responses. In different studies, these effects on DCs have translated into accelerated tumor progression, increased tumor-draining lymph node metastasis, immunotherapy failure, systemic dysfunctional immune status, and poor prognosis (102, 116, 120, 143-146). In summary, evidence suggests that tumor-induced DC defects are decisive for tumor growth, metastasis initiation, and prognosis. This emphasizes the impact of a phenotype shift in DCs in driving either immunosurveillance or accelerated malignant growth.

\section{NUMERICAL AND FUNCTIONAL DEFECTS OF DCS IN CRC PATIENTS}

Given the existence of different DC subsets and functional states, their plasticity in regard to signals from the TME and the 


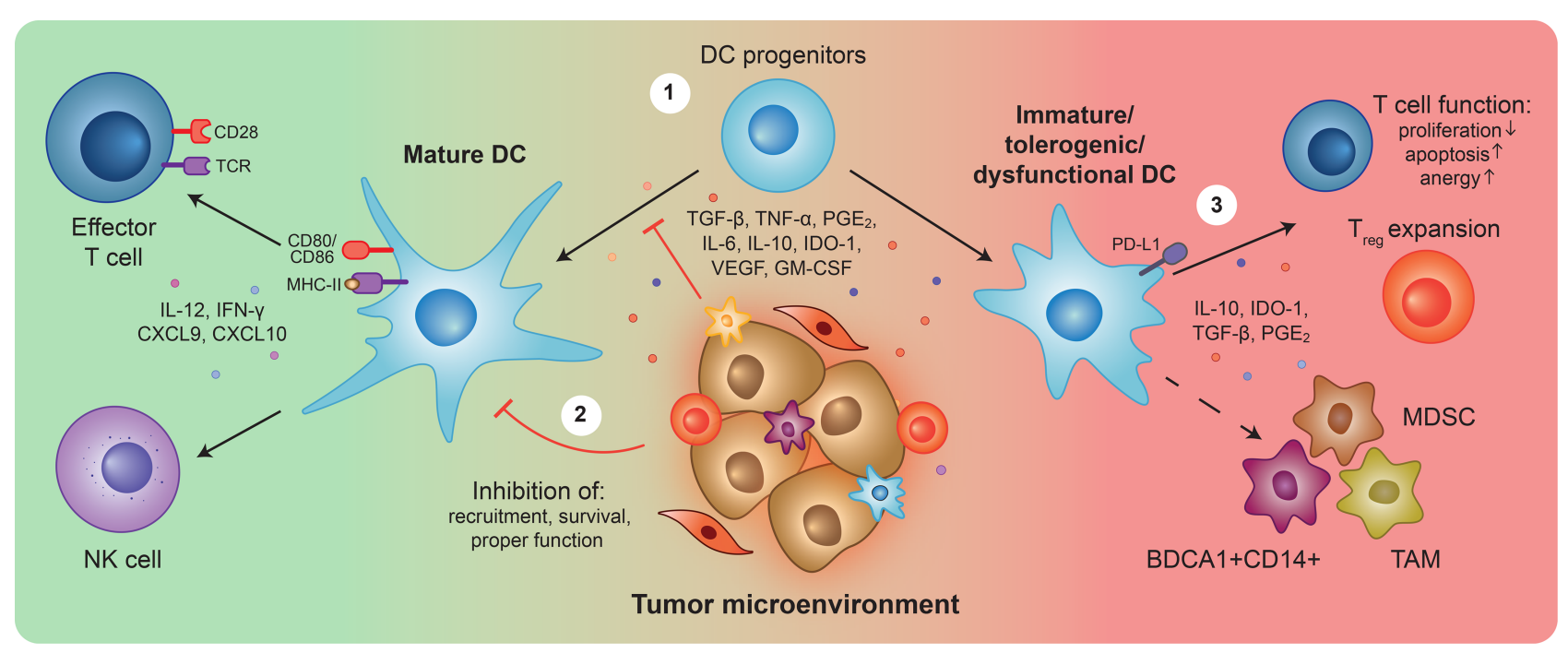

FIGURE 1 | Overview of Dendritic cell (dys)functions in cancer. Upon detection of tumor antigens and danger signals, dendritic cells (DCs) become activated, upregulate co-stimulatory surface molecules and secrete pro-inflammatory cytokines. Mature DCs can (cross)-present antigens, trigger tumor-specific T cell responses, and stimulate natural killer (NK) cell activity to unleash cytotoxic anti-tumor immunity (left). During tumor development and progression, the release of tumor-derived suppressive factors prevents DC progenitors from properly differentiating (1), and differentiated DCs from fulfilling their functions (2). Resulting immature, tolerogenic and/or dysfunctional DCs, characterized by the expression of TGF- $\beta$, IL-10, IDO-1, PGE2, and PD-L1, can inhibit T cell anti-tumor responses (3). Furthermore, they can differentiate into and favor the expansion of immunosuppressive populations such as myeloid-derived suppressor cells (MDSCs), BDCA1+CD14+ cells, and tumor-associated macrophages (TAMs). Overall, the impairment of DCs is a crucial step for tumor immune evasion, triggering a cascade of immunosuppression that hampers anti-tumor immunity and creates a propitious environment for tumor growth and metastasis initiation.

consequent impact on anti-tumor immunity, it is not surprising that DC phenotypical changes and defects have shown clinical relevance across different tumor types $(22,147,148)$. DCs have been widely investigated in CRC patients with variations in number, phenotype, and function of both circulating and TIDCs reported (Table $\mathbf{1}$ ).

Several studies have investigated the prognostic value and distribution pattern of TIDCs in CRC patients' tissues. DCs have been linked to both positive and negative effects on CRC prognosis, depending on their maturation status, location, and interaction with other immune tumor-infiltrating cells. Several studies have correlated a higher number of TIDCs with increased patient survival, lymphocyte infiltration, lower metastasis, and overall better prognosis $(66,149-154)$. In some of these studies, the S100 marker alone was used to identify DCs. These findings may be somewhat limited since S100 expression is restricted to only a few DC subsets, and is not a DC-specific marker being also expressed by other cell types including macrophages (183). Moreover, in these studies the maturation state of DCs was not assessed, which precludes information on DC pro- or antitumorigenic polarization and functions.

Further studies have investigated TIDCs distribution in CRC in correlation with their maturation status. Two studies report that the density of tumor-infiltrating mature DCs (mDCs) is lower in metastatic sites than in primary sites, which in turn is lower than in normal mucosa $(158,167)$. In addition, different studies have shown that $\mathrm{mDCs}$ are usually present in the invasive margin and cluster with T cells in lymphoid structures (TLS), whereas immature DCs (iDCs) are often more scattered through the tumor stoma $(159,160)$. These results suggest differential immune landscapes in primary and metastatic tumor sites and overall $\mathrm{mDC}$ exclusion from tumor sites.

Additionally, the maturation status of TIDCs has been correlated with disease progression and patient prognosis. Lower levels of mDC infiltrates have been linked to more advanced disease stage, higher metastatic burden, Treg infiltration, and poor prognosis. Conversely, higher levels of $\mathrm{mDCs}$ relative to iDCs, have been associated with stronger Th and CTL responses and better prognosis in general $(19,56,165,166,168-171)$. These results are in agreement with the anti-tumorigenic potential of $\mathrm{mDCs}$ and the tolerogenic role of iDCs. In line with this, MSI tumors with better survival are characterized by an increase in $\mathrm{mDC}$ and lower numbers of Tregs in comparison with MSS $(163,164)$. Two studies have shown somewhat contradicting results, implying a correlation between increased mDCs infiltration, and shorter survival and increased metastasis $(172,173)$. More recently, PD-L1+ DCs were clearly associated with CD8+ T cell infiltration and good survival in CRC (174). Interestingly, several studies have linked the observed defects of DCs and poorer survival with increased expression of COX-2, HMGB1, IL-6, and TGF- $\beta$ by CRC $(56,66,153,161,162$, 167). Of note, a limitation of many of these studies is the use of a small set, and often non-DC specific markers to characterize DCs and their maturation status. Notwithstanding, these studies certainly provide valuable insight on TIDCs distribution and prognostic value in CRC patients.

Besides TIDCs, numerical and functional defects of circulating DCs in CRC patients have also been observed. In general and in relation to disease progression, a decreased 
TABLE 1 | Overview of studies investigating tumor-infiltrating (TIDCs) and circulating dendritic cells (DCs) in colorectal cancer (CRC) patients.

\begin{tabular}{|c|c|c|c|c|}
\hline $\begin{array}{l}\text { CRC } \\
\text { (n) }\end{array}$ & $\begin{array}{l}\text { Experimental } \\
\text { setup }\end{array}$ & DC characterization & Key conclusions & Reference \\
\hline \multicolumn{5}{|c|}{ TIDCs - interactions with other immune cells and correlations with disease progression and prognosis } \\
\hline 121 & $\begin{array}{l}\text { Tissue } \\
\mathrm{IHC}\end{array}$ & S100 & $\begin{array}{l}\uparrow \text { S100+ DCs } \leftrightarrow \text { good prognosis, higher survival, often without } \\
\text { metastasis and } \uparrow \text { lymphocyte infiltration }\end{array}$ & $\begin{array}{l}\text { (Ambe, Mori, \& Enjoji, } \\
\text { 1989) } \\
(149)\end{array}$ \\
\hline 30 & $\begin{array}{l}\text { Tissue } \\
\mathrm{IHC}\end{array}$ & S100 & $\begin{array}{l}\uparrow \mathrm{S} 100+\mathrm{DCs} \leftrightarrow \text { good prognosis } \\
\downarrow \mathrm{S} 100+\mathrm{DCs} \leftrightarrow \text { lymph node and hepatic metastasis, >stage III }\end{array}$ & $\begin{array}{l}\text { (Nakayama et al., 2003) } \\
(150)\end{array}$ \\
\hline 104 & $\begin{array}{l}\text { Tissue } \\
\mathrm{IHC}\end{array}$ & S100 and HLA-II & $\uparrow$ S100+ DCs $\leftrightarrow \uparrow T$ cell infiltration and disease-free survival & $\begin{array}{l}\text { (Dadabayev et al., 2004) } \\
\text { (151) }\end{array}$ \\
\hline 40 & $\begin{array}{l}\text { Tissue } \\
\mathrm{IHC}\end{array}$ & $\begin{array}{l}\text { S100, CD11c, CD208, CD209, CD123, } \\
\text { and CD1a }\end{array}$ & $\begin{array}{l}\text { S100+DCs } \leftrightarrow \text { Tregs } \\
\uparrow \mathrm{S} 100+\mathrm{DCs} \leftrightarrow \text { prolonged survival } \\
\downarrow \mathrm{S} 100+\mathrm{DCs} \leftrightarrow \text { worse prognosis }\end{array}$ & $\begin{array}{l}\text { (Nagorsen et al., 2007) } \\
(152)\end{array}$ \\
\hline 16 & $\begin{array}{l}\text { Tissue } \\
\mathrm{IHC}\end{array}$ & CD205 & $\begin{array}{l}\downarrow \text { CD205+ DCs and high HMGB1 expression by CRC } \leftrightarrow \text { lymph } \\
\text { node metastasis }\end{array}$ & $\begin{array}{l}\text { (Kusume et al., 2009) } \\
(153)\end{array}$ \\
\hline 52 & $\begin{array}{l}\text { Tissue } \\
I H C\end{array}$ & CD11C+ & $\begin{array}{l}\downarrow \text { CD11c+ myeloid DCs } \uparrow \text { Tregs } \leftrightarrow \text { tumor invasion, advanced } \\
\text { stage, lymph node metastasis and poor prognosis }\end{array}$ & $\begin{array}{l}\text { (Gai, Li, Song, Lei, \& Yang, } \\
2013) \\
(154)\end{array}$ \\
\hline 63 & $\begin{array}{l}\text { Tissue } \\
\mathrm{IHC}\end{array}$ & $\begin{array}{l}\text { CD123 } \\
\text { (pDCs) }\end{array}$ & $\uparrow \mathrm{pDC} /$ myeloid DC ratio and $\uparrow$ Tregs $\leftrightarrow$ lymph node metastasis & $\begin{array}{l}\text { (Gai, Song, Li, Lei, \& Yang, } \\
\text { 2013) } \\
(155)\end{array}$ \\
\hline 149 & $\begin{array}{l}\text { Tissue } \\
\mathrm{IHC}\end{array}$ & $\mathrm{BDCA}-2+(\mathrm{pDCs})$ & $\uparrow \mathrm{pDC} \leftrightarrow \mathrm{TLS}$ and prolonged survival & $\begin{array}{l}\text { (Kießler et al., 2021) } \\
(156)\end{array}$ \\
\hline 58 & $\begin{array}{l}\text { Flow cytometry and } \\
\text { RNA sequencing }\end{array}$ & $\mathrm{BDCA}-2+(\mathrm{pDCs})$ & $\uparrow \mathrm{pDC} \downarrow$ innate lymphoid cells $\leftrightarrow$ advanced disease stage & $\begin{array}{l}\text { (Wu et al., 2021) } \\
(157)\end{array}$ \\
\hline \multicolumn{5}{|c|}{ TIDCs - maturation status and distribution } \\
\hline 57 & $\begin{array}{l}\text { Tissue } \\
\mathrm{IHC}\end{array}$ & CD83, HLA-DR, CD40, and CD86 & $\begin{array}{l}\text { Density of mDCs: Normal mucosa }>\text { primary } \mathrm{CRC}>\text { metastatic } \\
\text { CRC } \\
\text { No association with TGF- } \beta \text { or } \mathrm{IL}-10\end{array}$ & $\begin{array}{l}\text { (Schwaab, Weiss, Schned, } \\
\text { \& Barth, 2001) } \\
(158)\end{array}$ \\
\hline 17 & $\begin{array}{l}\text { Tissue } \\
\mathrm{IHC}\end{array}$ & $\begin{array}{l}\text { CD83 and } \\
\text { CD1a }\end{array}$ & $\begin{array}{l}\text { CD83+ mDCs: present in the invasive margin and cluster with } \\
\text { T cells } \\
\text { CD1a+ iDCs: scattered in the tumor stroma }\end{array}$ & $\begin{array}{l}\text { (Suzuki et al., 2002) } \\
(159)\end{array}$ \\
\hline 60 & $\begin{array}{l}\text { Tissue } \\
\mathrm{IHC}\end{array}$ & $\begin{array}{l}\text { CD1a, } \\
\text { S100, CD83, and HLA-DR }\end{array}$ & $\begin{array}{l}\text { CD83+ mDCs: present around metastases and in the } \\
\text { sinusoidal lumen } \\
\text { CD1a+ iDCs: scattered in the tumor stroma }\end{array}$ & $\begin{array}{l}\text { (M. Gulubova, Manolova, } \\
\text { Cirovski, \& Sivrev, 2008) } \\
(160)\end{array}$ \\
\hline 26 & $\begin{array}{l}\text { Tissue } \\
\mathrm{IHC} \text { and gene } \\
\text { expression }\end{array}$ & CD83 & $\begin{array}{l}\text { Primary site and lymph nodes: } \downarrow \text { CD83+ mDCs } \leftrightarrow \text { high COX2 } \\
\text { and IL-6 }\end{array}$ & $\begin{array}{l}\text { (Cui et al., 2007) } \\
(161)\end{array}$ \\
\hline 23 & $\begin{array}{l}\text { Tissue } \\
\mathrm{IHC} \text { and gene } \\
\text { expression }\end{array}$ & CD1a, CD83, and CD208 & $\begin{array}{l}\downarrow \mathrm{CD} 83+\mathrm{CD} 208+\mathrm{mDCs} \uparrow \mathrm{CD} 1 \mathrm{a}+\mathrm{iDCs} \leftrightarrow \text { increasing COX2 } \\
\text { expression }\end{array}$ & $\begin{array}{l}\text { (Yuan et al., 2008) } \\
(162)\end{array}$ \\
\hline 69 & $\begin{array}{l}\text { Tissue } \\
\mathrm{IHC}\end{array}$ & $\mathrm{S} 100, \mathrm{CD} 208$ & $\begin{array}{l}\text { In MSI tumors in comparison with MSS: } \uparrow \text { CD208+ mDCs and } \\
\downarrow \text { Tregs }\end{array}$ & $\begin{array}{l}\text { (Bauer et al., 2011) } \\
(163)\end{array}$ \\
\hline 133 & $\begin{array}{l}\text { Tissue } \\
\text { Gene expression }\end{array}$ & Genes implicated in immune response & $\begin{array}{l}\text { In MSI tumors in comparison with MSS: } \uparrow \text { co-stimulatory } \\
\text { molecules in DCs }\end{array}$ & $\begin{array}{l}\text { (Banerjea et al., 2004) } \\
(164)\end{array}$ \\
\hline \multicolumn{5}{|c|}{ TIDCs - maturation status and correlations with disease progression and prognosis } \\
\hline 70 & $\begin{array}{l}\text { Tissue } \\
\mathrm{IHC}\end{array}$ & CD83 & $\downarrow$ CD83+ mDCs $\leftrightarrow$ poor prognosis & $\begin{array}{l}\text { (Miyagawa et al., 2004) } \\
(165)\end{array}$ \\
\hline 22 & $\begin{array}{l}\text { Tissue } \\
\mathrm{IHC}\end{array}$ & CD83 & $\begin{array}{l}\downarrow \mathrm{CD} 83+\mathrm{mDCs} \leftrightarrow \text { advanced disease and lymph node } \\
\text { metastasis } \\
\uparrow \mathrm{CD} 83+\mathrm{mDCs} \text { and } \mathrm{IL}-12 \text { expression } \leftrightarrow \text { better prognosis }\end{array}$ & $\begin{array}{l}\text { (Inoeu et al., 2005) } \\
(166)\end{array}$ \\
\hline 142 & $\begin{array}{l}\text { Tissue } \\
\mathrm{IHC}\end{array}$ & HLA-DR, CD1a, and CD83 & $\begin{array}{l}\downarrow \mathrm{CD} 83+\mathrm{mDCs} \leftrightarrow \text { shorter survival } \leftrightarrow \text { TGF- } \beta \text { expression by } \\
\mathrm{CRC}\end{array}$ & $\begin{array}{l}\text { (Maya Gulubova et al., } \\
\text { 2010) } \\
(56)\end{array}$ \\
\hline 86 & $\begin{array}{l}\text { Tissue } \\
\mathrm{IHC}\end{array}$ & HLA-DR, CD1a, and CD83 & $\begin{array}{l}\text { Metastasis in comparison to metastasis-free samples: } \downarrow \text { CD83 } \\
+ \text { mDCs and } \uparrow \text { TGF- } \beta\end{array}$ & $\begin{array}{l}\text { (Maya Gulubova et al., } \\
\text { 2013) } \\
(167)\end{array}$ \\
\hline 44 & $\begin{array}{l}\text { Tissue } \\
\mathrm{IHC}\end{array}$ & CD1a and DC-LAMP & $\begin{array}{l}\downarrow T I L s \uparrow C D 1 a+i D C s / D C-L A M P+\text { mDCs ratio and } \mathrm{KRAS} \\
\text { mutation } \leftrightarrow \text { higher risk of disease recurrence }\end{array}$ & $\begin{array}{l}\text { (Kocián et al., 2011) } \\
(168)\end{array}$ \\
\hline 145 & $\begin{array}{l}\text { Tissue } \\
\mathrm{IHC}\end{array}$ & CD1a, S100, CD83, and HLA-DR & $\begin{array}{l}\downarrow \mathrm{CD} 83+\mathrm{HLA}-\mathrm{DR}+\mathrm{mDC} \text { in invasive margin } \leftrightarrow \text { advanced } \\
\text { stage (metastasis) and worse prognosis }\end{array}$ & $\begin{array}{l}\text { (Maya V. Gulubova et al., } \\
\text { 2012) } \\
(169)\end{array}$ \\
\hline
\end{tabular}


TABLE 1 | Continued

\begin{tabular}{|c|c|c|c|c|}
\hline $\begin{array}{l}\text { CRC } \\
\text { (n) }\end{array}$ & $\begin{array}{l}\text { Experimental } \\
\text { setup }\end{array}$ & DC characterization & Key conclusions & Reference \\
\hline 556 & Gene expression & Several DC-related genes & $\uparrow \operatorname{mDCs} \uparrow \top$ cells $\leftrightarrow$ low risk group & $\begin{array}{l}\text { (M. Li et al., 2020) } \\
(170)\end{array}$ \\
\hline 473 & Gene expression & CD80, CD83, and CD86 & $\begin{array}{l}\uparrow \mathrm{CD} 80+, \mathrm{CD} 83+, \mathrm{CD} 86+\text { mDCs } \leftrightarrow \text { CXCL8 expression by } \\
\mathrm{CRC}\end{array}$ & $\begin{array}{l}\text { (E. Li et al., 2021) } \\
(171)\end{array}$ \\
\hline 326 & Gene expression & Several DC-related genes & $\begin{array}{l}\uparrow \mathrm{DCs}, \mathrm{IL}-12 \text { and in TLS } \leftrightarrow \text { strong Th1 and CTL response and } \\
\text { more favorable prognostic }\end{array}$ & $\begin{array}{l}\text { (Coppola et al., 2011) } \\
\text { (19) }\end{array}$ \\
\hline 104 & $\begin{array}{l}\text { Tissue } \\
\mathrm{IHC}\end{array}$ & S100, CD1a, CD208, and HLA- II & $\begin{array}{l}\uparrow C D 208+\text { mDCs in the stroma } \leftrightarrow \text { shorter overall survival } \\
\uparrow C D 1 a+\text { iDCs in the advancing margin } \leftrightarrow \text { shorter disease-free } \\
\text { survival }\end{array}$ & $\begin{array}{l}\text { (Sandel et al., 2005) } \\
(172)\end{array}$ \\
\hline 71 & $\begin{array}{l}\text { Tissue } \\
\mathrm{IHC}\end{array}$ & CD83 & $\uparrow \mathrm{mDCs} \leftrightarrow$ tumor invasion and lymph node metastasis & $\begin{array}{l}\text { (Pryczynicz et al., 2016) } \\
\text { (173) }\end{array}$ \\
\hline 221 & $\begin{array}{l}\text { Tissue } \\
\mathrm{IHC}\end{array}$ & CD11c and PD-L1 & $\begin{array}{l}\uparrow \text { CD11C+ PD-L1+ DCs } \leftrightarrow \text { good survival and } \uparrow \text { CD8+ T cell } \\
\text { density }\end{array}$ & $\begin{array}{l}\text { (Miller et al., 2021) } \\
(174)\end{array}$ \\
\hline \multicolumn{5}{|c|}{ Blood circulating DCs - Numerical defects } \\
\hline 106 & Flow cytometry & HLA-DR and CD86 & $\downarrow$ Circulating DC $\leftrightarrow \uparrow$ TGF- $\beta$ levels & $\begin{array}{l}\text { (Huang et al., 2003) } \\
(175)\end{array}$ \\
\hline 54 & Flow cytometry & HLA-DR, CD11c, CD83, and CD86 & $\begin{array}{l}\text { Numerical and functional impairment of DC progenitors } \leftrightarrow \\
\text { stage of the disease and } \uparrow \text { VEGF levels }\end{array}$ & $\begin{array}{l}\text { (Della Porta et al., 2005) } \\
\text { (176) }\end{array}$ \\
\hline 27 & Flow cytometry & $\begin{array}{l}\text { BDCA-1, BDCA-2, BDCA-3, CD80, CD86, } \\
\text { and HLA-DR }\end{array}$ & $\begin{array}{l}\text { DCs number: healthy }>\text { metastatic }>\text { non-metastatic > } \\
\text { chemotherapy treated subjects }\end{array}$ & $\begin{array}{l}\text { (Bellik et al., 2006) } \\
(177)\end{array}$ \\
\hline 26 & Flow cytometry & CD33 and CD123 & $\downarrow$ CD123+ pDCs $\leftrightarrow$ advanced stage & $\begin{array}{l}\text { (Orsini et al., 2014) } \\
(178)\end{array}$ \\
\hline \multicolumn{5}{|c|}{ Blood circulating DCs - Functional defects } \\
\hline 31 & $\begin{array}{l}\text { Flow cytometry, } \\
\text { functional assays }\end{array}$ & $\begin{array}{l}\text { CD11c, CD123 } \\
\text { HLA-DR, CD80, CD86, and CD83 }\end{array}$ & $\begin{array}{l}\uparrow \text { immature myeloid cell progenitors } \\
\text { Defective DC maturation ex vivo } \leftrightarrow \uparrow \text { VEGF } \\
\text { Anti-VEGF antibody treatment: } \uparrow \text { ex vivo stimulatory capacity of } \\
\text { DC } \leftrightarrow \uparrow \text { antigen-specific allogenic } T \text { cell proliferation }\end{array}$ & $\begin{array}{l}\text { (Osada et al., 2008) } \\
(179)\end{array}$ \\
\hline 23 & $\begin{array}{l}\text { Flow cytometry, } \\
\text { functional assays }\end{array}$ & CD40, CD80, and CD83 & $\begin{array}{l}\text { Defective generation of mature and functional DC ex vivo } \leftrightarrow \\
\text { advanced disease stage } \\
\downarrow \text { Ability to present antigens to allogeneic T cells } \\
\uparrow I L-10 \downarrow I L-12 \text { and TNF- } \alpha\end{array}$ & $\begin{array}{l}\text { (Orsini et al., 2013) } \\
(180)\end{array}$ \\
\hline 16 & $\begin{array}{l}\text { Flow cytometry, } \\
\text { functional assays }\end{array}$ & $\begin{array}{l}\text { CD83 CD1a HLA-DR CD86 FITC, CD80, } \\
\text { CD209, and CD206 }\end{array}$ & Defective DC maturation ex vivo & $\begin{array}{l}\text { (Maciejewski et al., 2013) } \\
\text { (181) }\end{array}$ \\
\hline 30 & $\begin{array}{l}\text { Flow cytometry, } \\
\text { functional assays }\end{array}$ & $\begin{array}{l}\text { CD80, CD11c, HLA-ABC, HLA-DR, CD14, } \\
\text { CD133, CD11b, CD209, and CD86 }\end{array}$ & $\begin{array}{l}\text { Defective DC maturation ex vivo } \\
\downarrow \| \mathrm{L}-12\end{array}$ & $\begin{array}{l}\text { (Hsu et al., 2018) } \\
(182)\end{array}$ \\
\hline
\end{tabular}

$\leftrightarrow$ : correlation/association, $\uparrow$ higher infiltration/higher density/increase, $\downarrow$ lower infiltration/lower density/decrease. IHC, immunohistochemistry; mDCs, mature DCs; iDCs, immature DCs.

number of circulating DCs, increased number of progenitors, and a higher iDC/mDC ratio in CRC patients have been reported (175179). These defects have been associated with increased serum levels of TGF- $\beta$ and VEGF $(175,176,179)$. Furthermore, functional defects have been noted, including defective ex vivo differentiation and maturation of DCs from monocytes, tolerogenic phenotypes with decreased IL-12 and TNF- $\alpha$ release, increased release of IL-10 and TGF- $\beta$, and a compromised ability to induce allogenic T cell proliferation (179-182). These findings highlight the importance of systemic immunosuppression exerted by the CRC.

In addition, several studies have concluded that CRC explant tissue-conditioned medium inhibits LPS-induced in vitro DC maturation and function. In these assays, upregulation of costimulatory markers (CD80 and CD86) and PD-L1, and secretion of IL-12 and TNF- $\alpha$ was inhibited, while secretion of IL-10 was potentiated suggesting DCs acquire a tolerogenic phenotype (184187). One study even correlated stronger inhibition of DC maturation by CRC-conditioned medium with poorer survival in patients (186). A variety of tumor-derived factors secreted by CRC including VEGF, CCL2, CXCL1, and CXCL5, were shown to mediate these effects synergistically $(184,185)$. Collectively, these studies demonstrate that CRC, mainly through soluble mediators, evades anti-tumor responses by exerting local and systemic immunosuppression and disabling both infiltrating and circulating DCs.

Strikingly, very few studies have focused on the different DC subsets, which present different functional specializations, in relation to $\mathrm{CRC}$ and to $\mathrm{T}$ cell function. For instance, infiltration by $\mathrm{pDC}$ has yielded controversial results, with some studies associating pDCs infiltration with Treg development and poorer prognosis and others with increased survival, but without taking maturation status into account (155-157).

All in all, the reported findings illustrate the importance of local and systemic modulation of DCs in CRC. Currently, there are insufficient available data to elucidate on the complex mechanisms underlying DC dysfunction in CRC patients. To develop a more comprehensive picture of the implications of DC dysfunction in CRC, additional studies will be needed to determine the differential roles of the DC subsets in CRC, taking into account their functional specialization, maturation status and plasticity, which can have contrary impacts on tumor progression and prognosis (73). Moreover, further insight on the 
differences between metastatic and primary tumor sites will be of value.

\section{TUMOR-INDUCED DC DYSFUNCTION AND IMMUNOTHERAPY EFFICACY}

As illustrated in the previous section, the CRC immunosuppressive TME shifts the delicate balance of DCs from inflammation to tolerance, fueling disease progression and spread. In addition, DC dysregulation has also been implicated in patients' unresponsiveness to immunotherapies, further contributing to a poor prognosis. Current immunotherapeutic approaches for CRC have been mainly focused on targeting $\mathrm{T}$ cells, either by immune checkpoint inhibitors or by stimulating $\mathrm{T}$ cell activating receptors (188). However, only CRC patients harboring tumors with high mutational burden - MSI, accounting for less than $5 \%$ of the patients with mCRC - benefit from these treatments $(35,36)$.

Interestingly, in MSS CRC patients tumor-infiltrating neoantigen-specific $\mathrm{T}$ cells have been detected despite their low mutational burden and low responsiveness to immune checkpoint inhibitors (189). This and other data suggest that, upon treatment, tumor-specific $\mathrm{T}$ cells can be generated but are not functional $(47,189,190)$. This low $\mathrm{T}$ cell reactivity has been linked to a TGF- $\beta$-rich TME (189). Importantly, this T cellcentric approach of immunotherapy does not account for DC impairments, despite their crucial role in $\mathrm{T}$ cell priming, activation, and recruitment in the tumor bed.

Indeed, several studies have emphasized a strong dependency of effective immune checkpoint inhibition on correctly functioning and activated TIDCs. These studies confirm that cross-priming, licensing, and recruitment of $\mathrm{T}$ cells by functional intratumoral DCs is required for successful responses to antiPD-1 therapy and T cell adoptive therapy. And, that this is mainly mediated by CXCL9/10, IL-12, and IFN- $\gamma$ secretion by DCs $(85,123,191-195)$.

In line with this, one study in a melanoma model has shown that expansion and activation of TIDCs at the tumor site by recruiting and activating agents such as FLT3L and poly I:C, enhanced therapeutic response to immune checkpoint inhibitors (196). In addition, a recent study indicates that blocking CRCinduced WNT2 secretion by CAFs restores DC functions enhancing anti-PD-1 efficacy (197). These studies emphasize the importance of functional DCs in effective intra-tumoral DC$\mathrm{T}$ cell crosstalk for immunotherapy response. Therefore, targeting $\mathrm{T}$ cells without taking into account and resolving DC dysfunction might hamper the success of $\mathrm{T}$ cell-centered immunotherapies in CRC $(198,199)$.

Additionally, other studies show that NK cell and DC reciprocal interactions are required for enhanced $\mathrm{T}$ cell responses and determine responsiveness to immune checkpoint inhibition treatment $(200,201)$. NK cell frequency correlates with enhanced DC infiltration in the tumor, which in turn correlates with patient responsiveness to immune checkpoint inhibitors and increased survival. Moreover, studies have shown that DC vaccine efficacy is strongly dependent on NK cell activity and DC-NK cell crosstalk
(202-204). This highlights the importance of NK cells in tumor immunity not only by their ability to kill cancer cells directly, but also as promoters of DC activity.

In the clinic, studies with DC vaccines and other DC-targeting therapies in CRC have yielded modest results. DC vaccines consisting of ex vivo activated patient DCs, tailored against tumor-associated antigens, have the potential to trigger and boost $\mathrm{T}$ cell anti-tumor responses. This highly specific approach, combined with a relatively low risk of toxicity, makes DC vaccines particularly promising (10, 205). However, despite initial encouraging results including increased $\mathrm{T}$ cell responses and a good safety profile, $\mathrm{DC}$ vaccines have not shown strong therapeutic benefit in CRC patients (206-216). This is hypothesized to be linked to the strongly suppressive TME, particularly a TGF- $\beta$ rich TME $(10,217,218)$ and, consequently, defective and immunosuppressive DC populations. Besides suppressing administered DCs, these dysfunctional DC subsets can also limit T cell infiltration and effector function $(96,219)$. Current studies focus on improving vaccine platforms, increasing and expanding tumor specificity of vaccines, counteracting the host immunosuppressive mechanisms of resistance, and testing combinatorial therapies (220). Indeed, three ongoing or recently completed trials for mCRC aim to synergize DC vaccines with IL-2 (NCT02919644) or with immunological checkpoint inhibitors (NCT04912765 and NCT03152565). In conclusion, it seems that efficacy of immunotherapies is reliant on functional DCs for proper $\mathrm{T}$ cell-DC-NK cell crosstalk, which is disrupted by the strongly immunosuppressive TME.

\section{REVERTING DC DYSFUNCTION TO UNLEASH ANTI-TUMOR IMMUNITY AND RESPONSE TO IMMUNOTHERAPY}

Mounting evidence highlights the central role of DCs in anti-tumor immunity and consequently on immunotherapeutic responsiveness and urges the development of DC- and TMEtargeted therapies to tackle DC dysfunction in treatment-resistant CRC patients. Unleashing DCs emerges as a crucial step to make immune checkpoint inhibition and other immunotherapies available to all CRC patients. The development of combinatorial therapies for mCRC is being actively sought since monotherapies have not demonstrated effectiveness in improving patient's outcome (10). Since tumors evolved multiple mechanisms to avoid immune evasion, a multi-faceted approach focusing on different mechanisms will most likely be needed to address current issues in CRC treatment (10, 199, 221-223).

To breach the strong immunosuppressive CRC microenvironment, a promising therapeutic venue seems to include combinatorial strategies to in concert: 1) foster DC activation and function, boosting antigen presentation or TIDC abundance, 2) stimulate and unleash NK or T cells by immune checkpoint inhibition, and 3) target tumor-mediated mechanisms and tumor-released immunosuppressive factors. This should in principle allow overcoming of the strong suppressive TME, trigger more efficient NK-DC-T cell crosstalk and lead to full unleashing of local and systemic anti-tumor immune responses. As a metaphor this 
approach can be described as not only releasing the brakes of the immune system by lifting the vail of immunosuppression but also pressing the gas pedal by stimulating the key coordinators and effectors of immune responses.

The main aim of DC-targeting strategies is to skew the TIDC phenotype from tolerogenic to inflammatory, and enhance DCintrinsic abilities. Strategies that aim to restore and stimulate DC functions, although not powerful in the clinic alone, might have a key role in combinatorial treatments (10, 224-228). Approaches to circumvent tumor-mediated DC dysfunction can consist of DC vaccines or directly targeting and stimulating DCs in situ, by delivering DC-recruiting or promoting agents such as FLT3L, CpG, TLR and STING agonists (199). In addition, reverting DC dysfunction would break the positive feedback loop of immunosuppression, allowing wider reprogramming of the TME.

Thus far, overcoming the TME remains the most important and daunting challenge for CRC. Despite promising leads on the apparent key role of tumor-released suppressive factors such as TGF- $\beta$, VEGF, and PGE2, it is still largely unclear how CRC shapes DC fate. A more complete understanding of the complex web of interactions and elucidation on key mechanisms in play between CRC and DCs is required. Future studies will certainly provide new rationales and open doors for the design of novel therapies to unlock the full anti-tumor potential of DCs, while sensitizing previously unresponsive patients to immunotherapy.

\section{FUTURE PERSPECTIVES}

There is abundant room for further progress in understanding CRC-DC interactions. In future studies, it is important to consider both the functional and phenotypical plasticity of DCs subsets, and the heterogeneity and complexity of CRC. It is well-established that different DC subsets can have distinct, either complementary or opposing, functions in anti-tumor immunity and hence affect tumor progression differently (73). To better dissect this heterogeneity, further research is required to characterize the functional status, quantify, and assess the distribution of the different DC populations present in the tumor sites and in circulation in CRC patients. Whether these are correlated to CRC molecular subtype, disease progression, prognosis, treatment response or immunosuppressive systemic factors needs to be determined. Possibly, different subsets have different predictive potential and might arise as novel biomarkers for disease progression and treatment response. To get a comprehensive overview, patient material from different disease stages and molecular subtypes, including tissue sections, fresh biopsies and blood samples, will be valuable.

Furthermore, future research should aim to explore and study both metastatic and primary sites. There are few studies with a comparative perspective lens between primary and metastatic CRC. It is important to address differences in DCs infiltration, phenotype and functionality, and tumor-mediated evasion mechanisms. Metastatic sites are often different not only at a molecular level but also in the immune landscape and the TME.
Moreover, it is important to research metastases since these are often more resistant to therapy than their primary counterparts. As such, investigating and tackling the immunosuppressive environment of not only the primary tumor, but also the metastatic sites is of outermost importance (229).

At the molecular level, it is also important to gain insight on how CRC shapes the different DC subsets, what are the underlying mechanisms, and what are the local mediators of DC dysfunction. Also, many questions remain unanswered regarding how the different subsets correlate with each other and with $\mathrm{T}$ and NK cell effector function in CRC. To study in more detail these CRC-specific underlying molecular mechanisms, in vitro models are most suitable. Currently, there is a shortage of relevant and representative in vitro models to study the CRC TME.

Recently, patient-derived organoids (PDOs) are emerging as a powerful tool to study CRC heterogeneity and therapy responses by faithfully recapitulating many of the traits of patients' disease. Moreover, studying DCs in a tumor organoid context is still a largely unexplored field with a lot of opportunities. As such, 3D co-culture systems of DCs and CRC PDOs seem a promising approach to more closely study their interactions. In order to more representatively model the biological context and the in vivo interactions, higher complexity $3 \mathrm{D}$ co-culture models including stroma cells and different immune infiltrates that mimic the complex structure and composition of a tumor and its microenvironment are sought after (104, 230-232). In this line of research, recently a complex organotypic skin model was successfully developed to study DCs in melanoma (104). Hopefully in the near future, similar organotypic or complex 3D organoid based co-culture systems can be developed to study the CRC TME, both primary and metastatic, and follow the behavior of different subsets of DCs.

In addition, these models can possibly achieve sufficient physiological relevance to serve as testing platforms for novel therapies. This would be valuable since there are many unexplored combinatorial opportunities including TME- and DC-targeting therapies for CRC. It also remains to be determined which DC targeting strategies are effective and synergize with other immunotherapies in CRC patients. Furthermore, co-culture systems with PDOs offer the opportunity to test and tailor combinatorial strategies in a patient-specific manner.

\section{CONCLUSIONS}

Metastatic CRC remains one of the most aggressive and lethal cancers, with the large majority of patients being refractory to therapy. Disease aggressiveness and resistance to therapy has been linked to the tumor genetic makeup and a highly immunosuppressive TME. DCs have key roles in anti-tumor immunity, making them crucial targets for tumor evasion mechanisms. Overall, literature suggests that CRC-induced DC dysfunction is decisive for: impairing anti-tumor immune responses, tumor progression, metastatic colonization and 
initiation, and unresponsiveness to immunotherapies such as immune checkpoint blockage.

Unravelling the complex crosstalk between CRC and DCs and determining its significance for patients holds promise for identifying and modulating key mechanisms involved in disease progression. This opens doors for the design of novel strategies to reverse DC dysfunction. In principle, restoring DC functions can unlock the full anti-tumor potential of DCs and hence, unleash systemic anti-tumor immunity mediated by $\mathrm{T}$ and NK cells against primary and metastatic CRC. This approach should make immunotherapies available for more patients. Therefore, reverting DC dysfunction emerges as a promising path for CRC treatment and a critical pillar for combinatorial strategies. In order to design novel therapies, a completer and more comprehensive overview of the CRC TME and the mechanisms driving tumor progression and induction of DC tolerizing properties is necessary. For futures studies, examining patients' tissues and blood and development of in vitro TME coculture models based on PDOs appear as promising tools to obtain the missing knowledge.

\section{REFERENCES}

1. Rawla P, Sunkara T, Barsouk A. Epidemiology of Colorectal Cancer: Incidence, Mortality, Survival, and Risk Factors. Prz Gastroenterol (2019) 14:89-103. doi: 10.5114/pg.2018.81072

2. Siegel RL, Miller KD, Jemal A. Cancer Statistics, 2019. CA Cancer J Clin (2019) 69:7-34. doi: 10.3322/caac.21551

3. Siegel RL, Miller KD, Goding Sauer A, Fedewa SA, Butterly LF, Anderson JC, et al. Colorectal Cancer Statistics, 2020. CA Cancer J Clin (2020) 70:14564. doi: 10.3322/caac. 21601

4. Wang J, Li S, Liu Y, Zhang C, Li H, Lai B. Metastatic Patterns and Survival Outcomes in Patients With Stage IV Colon Cancer: A Population-Based Analysis. Cancer Med (2020) 9:361-73. doi: 10.1002/cam4.2673

5. Oki E, Ando K, Nakanishi R, Sugiyama M, Nakashima Y, Kubo N, et al. Recent Advances in Treatment for Colorectal Liver Metastasis. Ann Gastroenterol Surg (2018) 2:167-75. doi: 10.1002/ags3.12071

6. Gootjes EC, Stok EP, Buffart TE, Bakkerus L, Labots M, Zonderhuis BM, et al. Safety and Feasibility of Additional Tumor Debulking to First-Line Palliative Combination Chemotherapy for Patients With Multiorgan Metastatic Colorectal Cancer. Oncologist (2020) 25:e1195-201. doi: 10.1634/theoncologist.2019-0693

7. Cremolini C, Loupakis F, Antoniotti C, Lupi C, Sensi E, Lonardi S, et al. FOLFOXIRI Plus Bevacizumab Versus FOLFIRI Plus Bevacizumab as FirstLine Treatment of Patients With Metastatic Colorectal Cancer: Updated Overall Survival and Molecular Subgroup Analyses of the Open-Label, Phase 3 TRIBE Study. Lancet Oncol (2015) 16:1306-15. doi: 10.1016/S1470-2045(15)00122-9

8. Venook AP, Niedzwiecki D, Lenz H-J, Innocenti F, Fruth B, Meyerhardt JA, et al. Effect of First-Line Chemotherapy Combined With Cetuximab or Bevacizumab on Overall Survival in Patients With KRAS Wild-Type Advanced or Metastatic Colorectal Cancer. JAMA (2017) 317:2392. doi: 10.1001/jama.2017.7105

9. Heinemann V, von Weikersthal LF, Decker T, Kiani A, Vehling-Kaiser U, Al-Batran S-E, et al. FOLFIRI Plus Cetuximab Versus FOLFIRI Plus Bevacizumab as First-Line Treatment for Patients With Metastatic Colorectal Cancer (FIRE-3): A Randomised, Open-Label, Phase 3 Trial. Lancet Oncol (2014) 15:1065-75. doi: 10.1016/S1470-2045(14)70330-4

10. Janssen E, Subtil B, de la Jara Ortiz F, Verheul HMW, Tauriello DVF. Combinatorial Immunotherapies for Metastatic Colorectal Cancer. Cancers (Basel) (2020) 12:1875. doi: 10.3390/cancers12071875

11. Kalyan A, Kircher S, Shah H, Mulcahy M, Benson A. Updates on Immunotherapy for Colorectal Cancer. J Gastrointest Oncol (2018) 9:1609. doi: 10.21037/jgo.2018.01.17

\section{AUTHOR CONTRIBUTIONS}

BS performed literature searches and wrote the first version. All authors contributed to the article and approved the submitted version.

\section{FUNDING}

DT is funded by a Hypatia Tenure Track Fellowship grant from the Radboudumc and by the Netherlands Organisation for Scientific Research (NWO/ZonMW VIDI grant number 91719371). IV is funded by EU grant Oncobiome (825410) and Health Holland/SGF grant DC4Balance (LSHM18056-SGF).

\section{ACKNOWLEDGMENTS}

We would like to thank all members of the Cambi, Tauriello, and De Vries labs (Radboudumc Nijmegen) for valuable discussions.

12. Mittal D, Gubin MM, Schreiber RD, Smyth MJ. New Insights Into Cancer Immunoediting and its Three Component Phases-Elimination, Equilibrium and Escape. Curr Opin Immunol (2014) 27:16-25. doi: 10.1016/j.coi.2014.01.004

13. Tauriello DVF, Batlle E. Targeting the Microenvironment in Advanced Colorectal Cancer. Trends Cancer (2016) 2:495-504. doi: 10.1016/j.trecan.2016.08.001

14. Tauriello DVF, Palomo-Ponce S, Stork D, Berenguer-Llergo A, BadiaRamentol J, Iglesias $M$, et al. Tgf $\beta$ Drives Immune Evasion in Genetically Reconstituted Colon Cancer Metastasis. Nature (2018) 554:538-43. doi: 10.1038/nature25492

15. Gardner A, Ruffell B. Dendritic Cells and Cancer Immunity. Trends Immunol (2016) 37:855-65. doi: 10.1016/j.it.2016.09.006

16. Wculek SK, Cueto FJ, Mujal AM, Melero I, Krummel MF, Sancho D. Dendritic Cells in Cancer Immunology and Immunotherapy. Nat Rev Immunol (2019) 20:7-24. doi: 10.1038/s41577-019-0210-Z

17. Headley MB, Bins A, Nip A, Roberts EW, Looney MR, Gerard A, et al. Visualization of Immediate Immune Responses to Pioneer Metastatic Cells in the Lung. Nature (2016) 531:513-7. doi: 10.1038/nature16985

18. Goc J, Germain C, Vo-Bourgais TKD, Lupo A, Klein C, Knockaert S, et al. Dendritic Cells in Tumor-Associated Tertiary Lymphoid Structures Signal a Th1 Cytotoxic Immune Contexture and License the Positive Prognostic Value of Infiltrating CD8+ T Cells. Cancer Res (2014) 74:705-15. doi: 10.1158/0008-5472.CAN-13-1342

19. Coppola D, Nebozhyn M, Khalil F, Dai H, Yeatman T, Loboda A, et al. Unique Ectopic Lymph Node-Like Structures Present in Human Primary Colorectal Carcinoma Are Identified by Immune Gene Array Profiling. Am J Pathol (2011) 179:37-45. doi: 10.1016/j.ajpath.2011.03.007

20. Broz ML, Binnewies M, Boldajipour B, Nelson AE, Pollack JL, Erle DJ, et al. Dissecting the Tumor Myeloid Compartment Reveals Rare Activating Antigen-Presenting Cells Critical for T Cell Immunity. Cancer Cell (2014) 26:638-52. doi: 10.1016/j.ccell.2014.09.007

21. Tel J, Anguille S, Waterborg CEJ, Smits EL, Figdor CG, de Vries IJM. Tumoricidal Activity of Human Dendritic Cells. Trends Immunol (2014) 35:38-46. doi: 10.1016/j.it.2013.10.007

22. Vicari AP, Caux C, Trinchieri G. Tumour Escape From Immune Surveillance Through Dendritic Cell Inactivation. Semin Cancer Biol (2002) 12:33-42. doi: 10.1006/scbi.2001.0400

23. Legitimo A, Consolini R, Failli A, Orsini G, Spisni R. Dendritic Cell Defects in the Colorectal Cancer. Hum Vaccines Immunother (2014) 10:3224-35. doi: $10.4161 /$ hv. 29857

24. Nguyen H, Duong H. The Molecular Characteristics of Colorectal Cancer: Implications for Diagnosis and Therapy (Review). Oncol Lett (2018) 16:918. doi: $10.3892 /$ ol.2018.8679 
25. Ganesh K, Stadler ZK, Cercek A, Mendelsohn RB, Shia J, Segal NH, et al. Immunotherapy in Colorectal Cancer: Rationale, Challenges and Potential. Nat Rev Gastroenterol Hepatol (2019) 16:361-75. doi: 10.1038/s41575-0190126-x

26. Sadanandam A, Lyssiotis CA, Homicsko K, Collisson EA, Gibb WJ, Wullschleger S, et al. A Colorectal Cancer Classification System That Associates Cellular Phenotype and Responses to Therapy. Nat Med (2013) 19:619-25. doi: 10.1038/nm.3175

27. Marisa L, de Reynies A, Duval A, Selves J, Gaub MP, Vescovo L, et al. Gene Expression Classification of Colon Cancer Into Molecular Subtypes: Characterization, Validation, and Prognostic Value. PloS Med (2013) 10: e1001453. doi: 10.1371/journal.pmed.1001453

28. Fridman WH, Miller I, Sautès-Fridman C, Byrne AT. Therapeutic Targeting of the Colorectal Tumor Stroma. Gastroenterology (2020) 158:303-21. doi: 10.1053/j.gastro.2019.09.045

29. Valle L, Vilar E, Tavtigian SV, Stoffel EM. Genetic Predisposition to Colorectal Cancer: Syndromes, Genes, Classification of Genetic Variants and Implications for Precision Medicine. J Pathol (2019) 247:574-88. doi: $10.1002 /$ path.5229

30. Kanth P, Grimmett J, Champine M, Burt R, Samadder NJ. Hereditary Colorectal Polyposis and Cancer Syndromes: A Primer on Diagnosis and Management. Am J Gastroenterol (2017) 112:1509-25. doi: 10.1038/ ajg.2017.212

31. Tariq K, Ghias K. Colorectal Cancer Carcinogenesis: A Review of Mechanisms. Cancer Biol Med (2016) 13:120-35. doi: 10.28092/j.issn. 2095-3941.2015.0103

32. Nguyen LH, Goel A, Chung DC. Pathways of Colorectal Carcinogenesis. Gastroenterology (2020) 158:291-302. doi: 10.1053/j.gastro.2019.08.059

33. Gupta R, Sinha S, Paul RN. The Impact of Microsatellite Stability Status in Colorectal Cancer. Curr Probl Cancer (2018) 42:548-59. doi: 10.1016/ j.currproblcancer.2018.06.010

34. Westdorp H, Fennemann FL, Weren RDA, Bisseling TM, Ligtenberg MJL, Figdor CG, et al. Opportunities for Immunotherapy in Microsatellite Instable Colorectal Cancer. Cancer Immunol Immunother (2016) 65:124959. doi: $10.1007 / \mathrm{s} 00262-016-1832-7$

35. Le DT, Uram JN, Wang H, Bartlett BR, Kemberling H, Eyring AD, et al. PD1 Blockade in Tumors With Mismatch-Repair Deficiency. N Engl J Med (2015) 372:2509-20. doi: 10.1056/NEJMoa1500596

36. Overman MJ, Kopetz S, McDermott RS, Leach J, Lonardi S, Lenz H-J, et al. Nivolumab \pm Ipilimumab in Treatment (Tx) of Patients (Pts) With Metastatic Colorectal Cancer (mCRC) With and Without High Microsatellite Instability (MSI-H): CheckMate-142 Interim Results. J Clin Oncol (2016) 34:3501-1. doi: 10.1200/jco.2016.34.15_suppl.3501

37. Joyce JA, Fearon DT. T Cell Exclusion, Immune Privilege, and the Tumor Microenvironment. Sci (80- ) (2015) 348:74-80. doi: 10.1126/science. aaa6204

38. Borelli B, Fontana E, Giordano M, Antoniotti C, Lonardi S, Bergamo F, et al. Prognostic and Predictive Impact of Consensus Molecular Subtypes and CRCAssigner Classifications in Metastatic Colorectal Cancer: A Translational Analysis of the TRIBE2 Study. ESMO Open (2021) 6:100073. doi: 10.1016/j.esmoop.2021.100073

39. Guinney J, Dienstmann R, Wang X, de Reyniès A, Schlicker A, Soneson C, et al. The Consensus Molecular Subtypes of Colorectal Cancer. Nat Med (2015) 21:1350-6. doi: 10.1038/nm.3967

40. Calon A, Lonardo E, Berenguer-Llergo A, Espinet E, Hernando-Momblona $\mathrm{X}$, Iglesias $\mathrm{M}$, et al. Stromal Gene Expression Defines Poor-Prognosis Subtypes in Colorectal Cancer. Nat Genet (2015) 47:320-9. doi: 10.1038/ ng.3225

41. Tauriello DVF, Calon A, Lonardo E, Batlle E. Determinants of Metastatic Competency in Colorectal Cancer. Mol Oncol (2017) 11:97-119. doi: $10.1002 / 1878-0261.12018$

42. Balkwill FR, Capasso M, Hagemann T. The Tumor Microenvironment at a Glance. J Cell Sci (2012) 125:5591-6. doi: 10.1242/jcs.116392

43. Quail DF, Joyce JA. Microenvironmental Regulation of Tumor Progression and Metastasis. Nat Med (2013) 19:1423-37. doi: 10.1038/nm.3394

44. Hanahan D, Coussens LM. Accessories to the Crime: Functions of Cells Recruited to the Tumor Microenvironment. Cancer Cell (2012) 21:309-22. doi: $10.1016 /$ j.ccr.2012.02.022
45. Pietras K, Östman A. Hallmarks of Cancer: Interactions With the Tumor Stroma. Exp Cell Res (2010) 316:1324-31. doi: 10.1016/J.YEXCR.2010.02.045

46. McLean MH, Murray GI, Stewart KN, Norrie G, Mayer C, Hold GL, et al. The Inflammatory Microenvironment in Colorectal Neoplasia. PloS One (2011) 6:e15366. doi: 10.1371/journal.pone.0015366

47. Galon J, Costes A, Sanchez-Cabo F, Kirilovsky A, Mlecnik B, Lagorce-Pagès C, et al. Type, Density, and Location of Immune Cells Within Human Colorectal Tumors Predict Clinical Outcome. Sci (80- ) (2006) 313:1960-4. doi: 10.1126/science.1129139

48. Lasry A, Zinger A, Ben-Neriah Y. Inflammatory Networks Underlying Colorectal Cancer. Nat Immunol (2016) 17:230-40. doi: 10.1038/ni.3384

49. Croci DO, Zacarías Fluck MF, Rico MJ, Matar P, Rabinovich GA, Scharovsky OG. Dynamic Cross-Talk Between Tumor and Immune Cells in Orchestrating the Immunosuppressive Network at the Tumor Microenvironment. Cancer Immunol Immunother (2007) 56:1687-700. doi: 10.1007/s00262-007-0343-y

50. Shi Y, Li Z, Zheng W, Liu X, Sun C, Laugsand JB, et al. Changes of Immunocytic Phenotypes and Functions From Human Colorectal Adenomatous Stage to Cancerous Stage: Update. Immunobiology (2015) 220:1186-96. doi: 10.1016/j.imbio.2015.06.003

51. Gessani S, Belardelli F. Immune Dysfunctions and Immunotherapy in Colorectal Cancer: The Role of Dendritic Cells. Cancers (Basel) (2019) 11:1491. doi: 10.3390/cancers11101491

52. Fares J, Fares MY, Khachfe HH, Salhab HA, Fares Y. Molecular Principles of Metastasis: A Hallmark of Cancer Revisited. Signal Transduct Target Ther (2020) 5:1-17. doi: 10.1038/s41392-020-0134-x

53. Batlle E, Massagué J. Transforming Growth Factor- $\beta$ Signaling in Immunity and Cancer. Immunity (2019) 50:924-40. doi: 10.1016/j.immuni.2019.03.024

54. Yang L, Pang Y, Moses HL. TGF- $\beta$ and Immune Cells: An Important Regulatory Axis in the Tumor Microenvironment and Progression. Trends Immunol (2010) 31:220-7. doi: 10.1016/j.it.2010.04.002

55. Zhang B, Halder SK, Zhang S, Datta PK. Targeting Transforming Growth Factor- $\beta$ Signaling in Liver Metastasis of Colon Cancer. Cancer Lett (2009) 277:114-20. doi: 10.1016/j.canlet.2008.11.035

56. Gulubova M, Manolova I, Ananiev J, Julianov A, Yovchev Y, Peeva K. Role of TGF- $\beta 1$, Its Receptor Tgfßrii, and Smad Proteins in the Progression of Colorectal Cancer. Int J Colorectal Dis (2010) 25:591-9. doi: 10.1007/s00384010-0906-9

57. Tsushima H, Ito N, Tamura S, Matsuda Y, Inada M, Yabuuchi I, et al. Circulating Transforming Growth Factor $\beta 1$ as a Predictor of Liver Metastasis After Resection in Colorectal Cancer. Clin Cancer Res (2001) 7:1258-62.

58. Calon A, Espinet E, Palomo-Ponce S, Tauriello DVF, Iglesias M, Céspedes MV, et al. Dependency of Colorectal Cancer on a TGF- $\beta$-Driven Program in Stromal Cells for Metastasis Initiation. Cancer Cell (2012) 22:571-84. doi: 10.1016/j.ccr.2012.08.013

59. Calon A, Tauriello DVF, Batlle E. TGF-Beta in CAF-Mediated Tumor Growth and Metastasis. Semin Cancer Biol (2014) 25:15-22. doi: 10.1016/ j.semcancer.2013.12.008

60. Flavell RA, Sanjabi S, Wrzesinski SH, Licona-Limón P. The Polarization of Immune Cells in the Tumour Environment by TGFî 2. Nat Rev Immunol (2010) 10:554-67. doi: 10.1038/nri2808

61. Demaria O, Cornen S, Daëron M, Morel Y, Medzhitov R, Vivier E. Harnessing Innate Immunity in Cancer Therapy. Nature (2019) 574:4556. doi: $10.1038 / \mathrm{s} 41586-019-1593-5$

62. Villalba M, Evans SR, Vidal-Vanaclocha F, Calvo A. Role of TGF- $\beta$ in Metastatic Colon Cancer: It Is Finally Time for Targeted Therapy. Cell Tissue Res (2017) 370:29-39. doi: 10.1007/s00441-017-2633-9

63. Toyoshima Y, Kitamura H, Xiang H, Ohno Y, Homma S, Kawamura H, et al. IL6 Modulates the Immune Status of the Tumor Microenvironment to Facilitate Metastatic Colonization of Colorectal Cancer Cells. Cancer Immunol Res (2019) 7:1944-57. doi: 10.1158/2326-6066.CIR-18-0766

64. Zhang Y, Davis C, Shah S, Hughes D, Ryan JC, Altomare D, et al. IL-33 Promotes Growth and Liver Metastasis of Colorectal Cancer in Mice by Remodeling the Tumor Microenvironment and Inducing Angiogenesis. Mol Carcinog (2016) 56:272-87. doi: 10.1002/mc.22491

65. Chang J, Vacher J, Yao B, Fan X, Zhang B, Harris RC, et al. Prostaglandin E Receptor 4 (EP4) Promotes Colonic Tumorigenesis. Oncotarget (2015) 6:33500-11. doi: 10.18632/oncotarget.5589 
66. Wendum D, Masliah J, Trugnan G, Fléjou JF. Cyclooxygenase-2 and Its Role in Colorectal Cancer Development. Virchows Arch (2004) 445:327-33. doi: $10.1007 / \mathrm{s} 00428-004-1105-2$

67. Schetter AJ, Giang HN, Bowman ED, Mathé EA, Siu TY, Hawkes JE, et al. Association of Inflammation-Related and microRNA Gene Expression With Cancer-Specific Mortality of Colon Adenocarcinoma. Clin Cancer Res (2009) 15:5878-87. doi: 10.1158/1078-0432.CCR-09-0627

68. Liu X, Zhu L, Lu X, Bian H, Wu X, Yang W, et al. IL-33/ST2 Pathway Contributes to Metastasis of Human Colorectal Cancer. Biochem Biophys Res Commun (2014) 453:486-92. doi: 10.1016/j.bbrc.2014.09.106

69. Kortylewski M, Xin H, Kujawski M, Lee H, Liu Y, Harris T, et al. Regulation of the IL-23 and IL-12 Balance by Stat3 Signaling in the Tumor Microenvironment. Cancer Cell (2009) 15:114-23. doi: 10.1016/j.ccr.2008.12.018

70. Brandacher G, Perathoner A, Ladurner R, Schneeberger S, Obrist P, Winkler C, et al. Prognostic Value of Indoleamine 2,3-Dioxygenase Expression in Colorectal Cancer: Effect on Tumor-Infiltrating T Cells. Clin Cancer Res (2006) 12:1144-51. doi: 10.1158/1078-0432.CCR-05-1966

71. Munn DH, Shafizadeh E, Attwood JT, Bondarev I, Pashine A, Mellor AL. Inhibition of T Cell Proliferation by Macrophage Tryptophan Catabolism. J Exp Med (1999) 189:1363-72. doi: 10.1084/jem.189.9.1363

72. Mezrich JD, Fechner JH, Zhang X, Johnson BP, Burlingham WJ, Bradfield CA. An Interaction Between Kynurenine and the Aryl Hydrocarbon Receptor Can Generate Regulatory T Cells. J Immunol (2010) 185:3190-8. doi: 10.4049/jimmunol.0903670

73. Laoui D, Keirsse J, Morias Y, Van Overmeire E, Geeraerts X, Elkrim Y, et al. The Tumour Microenvironment Harbours Ontogenically Distinct Dendritic Cell Populations With Opposing Effects on Tumour Immunity. Nat Commun (2016) 7:13720. doi: 10.1038/ncomms 13720

74. Böttcher JP, Bonavita E, Chakravarty P, Blees H, Cabeza-Cabrerizo M, Sammicheli S, et al. NK Cells Stimulate Recruitment of Cdc1 Into the Tumor Microenvironment Promoting Cancer Immune Control. Cell (2018) 172:1022-1037.e14. doi: 10.1016/J.CELL.2018.01.004

75. Carenza C, Calcaterra F, Oriolo F, Di Vito C, Ubezio M, Della PMG, et al. Bella S Della. Costimulatory Molecules and Immune Checkpoints Are Differentially Expressed on Different Subsets of Dendritic Cells. Front Immunol (2019) 10:1325. doi: 10.3389/fimmu.2019.01325

76. Kim MK, Kim J. Properties of Immature and Mature Dendritic Cells: Phenotype, Morphology, Phagocytosis, and Migration. RSC Adv (2019) 9:11230-8. doi: 10.1039/C9RA00818G

77. Dudek AM, Martin S, Garg AD, Agostinis P. Immature, Semi-Mature, and Fully Mature Dendritic Cells: Toward a DC-Cancer Cells Interface That Augments Anticancer Immunity. Front Immunol (2013) 4:438. doi: 10.3389/ fimmu.2013.00438

78. Cerboni S, Gentili M, Manel N. (2013). Diversity of Pathogen Sensors in Dendritic Cells. Adv Immunol 120:211-37. doi: 10.1016/B978-0-12-4170285.00008-9

79. Tang M, Diao J, Cattral MS. Molecular Mechanisms Involved in Dendritic Cell Dysfunction in Cancer. Cell Mol Life Sci (2017) 74:761-76. doi: 10.1007/ s00018-016-2317-8

80. Ruffell B, Chang-Strachan D, Chan V, Rosenbusch A, Ho CMT, Pryer N, et al. Macrophage IL-10 Blocks CD8+ T Cell-Dependent Responses to Chemotherapy by Suppressing IL-12 Expression in Intratumoral Dendritic Cells. Cancer Cell (2014) 26:623-37. doi: 10.1016/j.ccell.2014.09.006

81. Engelhardt JJ, Boldajipour B, Beemiller P, Pandurangi P, Sorensen C, Werb $Z$, et al. Marginating Dendritic Cells of the Tumor Microenvironment CrossPresent Tumor Antigens and Stably Engage Tumor-Specific T Cells. Cancer Cell (2012) 21:402-17. doi: 10.1016/j.ccr.2012.01.008

82. Bennett CL, Chakraverty R. Dendritic Cells in Tissues: In Situ Stimulation of Immunity and Immunopathology. Trends Immunol (2012) 33:8-13. doi: 10.1016/j.it.2011.09.008

83. Sánchez-Paulete AR, Teijeira A, Cueto FJ, Garasa S, Pérez-Gracia JL, Sánchez-Arráez A, et al. Antigen Cross-Presentation and T-Cell CrossPriming in Cancer Immunology and Immunotherapy. Ann Oncol (2017) 28: xii44-55. doi: 10.1093/annonc/mdx237

84. Roberts EW, Broz ML, Binnewies M, Headley MB, Nelson AE, Wolf DM, et al. Critical Role for CD103+/CD141+ Dendritic Cells Bearing CCR7 for Tumor Antigen Trafficking and Priming of T Cell Immunity in Melanoma. Cancer Cell (2016) 30:324-36. doi: 10.1016/j.ccell.2016.06.003
85. Pfirschke C, Siwicki M, Liao HW, Pittet MJ. Tumor Microenvironment: No Effector T Cells Without Dendritic Cells. Cancer Cell (2017) 31:614-5. doi: 10.1016/j.ccell.2017.04.007

86. Calmeiro J, Carrascal M, Gomes C, Falcão A, Cruz MT, Neves BM. Highlighting the Role of DC-NK Cell Interplay in Immunobiology and Immunotherapy. In: Dendritic Cells. InTech (2018). p. 25-45. doi: 10.5772/ intechopen.78804

87. Gerosa F, Baldani-Guerra B, Nisii C, Marchesini V, Carra G, Trinchieri G. Reciprocal Activating Interaction Between Natural Killer Cells and Dendritic Cells. J Exp Med (2002) 195:327-33. doi: 10.1084/jem.20010938

88. Banchereau J, Steinman RM. Dendritic Cells and the Control of Immunity. Nature (1998) 392:245-52. doi: 10.1038/32588

89. Collin M, Bigley V. Human Dendritic Cell Subsets: An Update. Immunology (2018) 154:3-20. doi: 10.1111/imm.12888

90. Shin KS, Jeon I, Kim BS, Kim IK, Park YJ, Koh CH, et al. Monocyte-Derived Dendritic Cells Dictate the Memory Differentiation of CD8+ T Cells During Acute Infection. Front Immunol (2019) 10:1887. doi: 10.3389/fimmu. 2019.01887

91. Tang-Huau TL, Gueguen P, Goudot C, Durand M, Bohec M, Baulande S, et al. Human In Vivo-Generated Monocyte-Derived Dendritic Cells and Macrophages Cross-Present Antigens Through a Vacuolar Pathway. Nat Commun (2018) 9:1-12. doi: 10.1038/s41467-018-04985-0

92. Rhodes JW, Tong O, Harman AN, Turville SG. Human Dendritic Cell Subsets, Ontogeny, and Impact on HIV Infection. Front Immunol (2019) 10:1088. doi: 10.3389/fimmu.2019.01088

93. Kushwah R, Hu J. Complexity of Dendritic Cell Subsets and Their Function in the Host Immune System. Immunology (2011) 133:409-19. doi: 10.1111/ j.1365-2567.2011.03457.x

94. Lutz MB, Schuler G. Immature, Semi-Mature and Fully Mature Dendritic Cells: Which Signals Induce Tolerance or Immunity? Trends Immunol (2002) 23:445-9. doi: 10.1016/S1471-4906(02)02281-0

95. Hargadon KM. Tumor-Altered Dendritic Cell Function: Implications for Anti-Tumor Immunity. Front Immunol (2013) 4:192. doi: 10.3389/ fimmu.2013.00192

96. van Ee TJ, Van Acker HH, van Oorschot TG, Van Tendeloo VF, Smits EL, Bakdash G, et al. BDCA1+CD14+ Immunosuppressive Cells in Cancer, a Potential Target? Vaccines (2018) 6:65. doi: 10.3390/vaccines6030065

97. Kiertscher SM, Luo J, Dubinett SM, Roth MD. Tumors Promote Altered Maturation and Early Apoptosis of Monocyte-Derived Dendritic Cells. J Immunol (2000) 164:1269-76. doi: 10.4049/jimmunol.164.3.1269

98. Failli A, Legitimo A, Orsini G, Romanini A, Consolini R. Numerical Defect of Circulating Dendritic Cell Subsets and Defective Dendritic Cell Generation From Monocytes of Patients With Advanced Melanoma. Cancer Lett (2013) 337:184-92. doi: 10.1016/j.canlet.2013.05.013

99. Nefedova Y, Huang M, Kusmartsev S, Bhattacharya R, Cheng P, Salup R, et al. Hyperactivation of STAT3 Is Involved in Abnormal Differentiation of Dendritic Cells in Cancer. J Immunol (2004) 172:464-74. doi: 10.4049/ jimmunol.172.1.464

100. Sciarra A, Lichtner M, Autran Gomez AM, Mastroianni C, Rossi R, Mengoni F, et al. Characterization of Circulating Blood Dendritic Cell Subsets DC123+ (Lymphoid) and DC11C+ (Myeloid) in Prostate Adenocarcinoma Patients. Prostate (2007) 67:1-7. doi: 10.1002/pros.20431

101. Almand B, Clark JI, Nikitina E, van Beynen J, English NR, Knight SC, et al. Increased Production of Immature Myeloid Cells in Cancer Patients: A Mechanism of Immunosuppression in Cancer. J Immunol (2001) 166:67889. doi: 10.4049/jimmunol.166.1.678

102. Hegde S, Krisnawan VE, Herzog BH, Zuo C, Breden MA, Knolhoff BL, et al. Dendritic Cell Paucity Leads to Dysfunctional Immune Surveillance in Pancreatic Cancer. Cancer Cell (2020) 37:289-307.e9. doi: 10.1016/ j.ccell.2020.02.008

103. Hoffmann TK, Müller-Berghaus J, Ferris RL, Johnson JT, Storkus WJ, Whiteside TL. Alterations in the Frequency of Dendritic Cell Subsets in the Peripheral Circulation of Patients With Squamous Cell Carcinomas of the Head and Neck. Clin Cancer Res (2002) 8:1787-93.

104. Di Blasio S, van Wigcheren GF, Becker A, van Duffelen A, Gorris M, Verrijp $\mathrm{K}$, et al. The Tumour Microenvironment Shapes Dendritic Cell Plasticity in a Human Organotypic Melanoma Culture. Nat Commun (2020) 11:2749. doi: 10.1038/s41467-020-16583-0 
105. Lin JH, Huffman AP, Wattenberg MM, Walter DM, Carpenter EL, Feldser DM, et al. Type 1 Conventional Dendritic Cells Are Systemically Dysregulated Early in Pancreatic Carcinogenesis. J Exp Med (2020) 217: e20190673. doi: 10.1084/jem.20190673

106. Brown RD, Pope B, Murray A, Esdale W, Sze DM, Gibson J, et al. Dendritic Cells From Patients With Myeloma Are Numerically Normal But Functionally Defective as They Fail to Up-Regulate CD80 (B7-1) Expression After Hucd40lt Stimulation Because of Inhibition by Transforming Growth Factor- $\beta 1$ and Interleukin-10. Blood (2001) 98:2992-8. doi: 10.1182/blood.V98.10.2992

107. Ratta M, Fagnoni F, Curti A, Vescovini R, Sansoni P, Oliviero B, et al. Dendritic Cells Are Functionally Defective in Multiple Myeloma: The Role of Interleukin-6. Blood (2002) 100:230-7. doi: 10.1182/blood.V100.1.230

108. Shurin MR, Yurkovetsky ZR, Tourkova IL, Balkir L, Shurin GV. Inhibition of CD40 Expression and CD40-Mediated Dendritic Cell Function by TumorDerived IL-10. Int J Cancer (2002) 101:61-8. doi: 10.1002/ijc.10576

109. Bharadwaj U, Li M, Zhang R, Chen C, Yao Q. Elevated Interleukin-6 and GCSF in Human Pancreatic Cancer Cell Conditioned Medium Suppress Dendritic Cell Differentiation and Activation. Cancer Res (2007) 67:547988. doi: 10.1158/0008-5472.CAN-06-3963

110. Bekeredjian-Ding I, Schäfer M, Hartmann E, Pries R, Parcina M, Schneider P, et al. Tumour-Derived Prostaglandin E 2 and Transforming Growth Factor- $\beta$ Synergize to Inhibit Plasmacytoid Dendritic Cell-Derived Interferon- $\alpha$. Immunology (2009) 128:439-50. doi: 10.1111/j.13652567.2009.03134.x

111. Beckebaum S, Zhang X, Chen X, Yu Z, Frilling A, Dworacki G, et al. Increased Levels of Interleukin-10 in Serum From Patients With Hepatocellular Carcinoma Correlate With Profound Numerical Deficiencies and Immature Phenotype of Circulating Dendritic Cell Subsets. Clin Cancer Res (2004) 10:7260-9. doi: 10.1158/1078-0432.CCR-04-0872

112. Zong J, Keskinov AA, Shurin GV, Shurin MR. Tumor-Derived Factors Modulating Dendritic Cell Function. Cancer Immunol Immunother (2016) 65:821-33. doi: 10.1007/s00262-016-1820-y

113. Sisirak V, Vey N, Goutagny N, Renaudineau S, Malfroy M, Thys S, et al. Breast Cancer-Derived Transforming Growth Factor- $\beta$ and Tumor Necrosis Factor- $\alpha$ Compromise Interferon- $\alpha$ Production by Tumor-Associated Plasmacytoid Dendritic Cells. Int J Cancer (2013) 133:771-8. doi: 10.1002/ ijc. 28072

114. Dumitriu IE, Dunbar DR, Howie SE, Sethi T, Gregory CD. Human Dendritic Cells Produce TGF- $\beta 1$ Under the Influence of Lung Carcinoma Cells and Prime the Differentiation of CD4 + CD25 + Foxp3 + Regulatory T Cells. J Immunol (2009) 182:2795-807. doi: 10.4049/jimmunol.0712671

115. Song S, Yuan P, Wu H, Chen J, Fu J, Li P, et al. Dendritic Cells With an Increased PD-L1 by TGF- $\beta$ Induce T Cell Anergy for the Cytotoxicity of Hepatocellular Carcinoma Cells. Int Immunopharmacol (2014) 20:117-23. doi: 10.1016/j.intimp.2014.02.027

116. Imai K, Minamiya Y, Koyota S, Ito M, Saito H, Sato Y, et al. Inhibition of Dendritic Cell Migration by Transforming Growth Factor-1 Increases Tumor-Draining Lymph Node Metastasis. J Exp Clin Cancer Res (2012) 31:1-9. doi: 10.1186/1756-9966-31-3

117. Della Bella S, Gennaro M, Vaccari M, Ferraris C, Nicola S, Riva A, et al. Altered Maturation of Peripheral Blood Dendritic Cells in Patients With Breast Cancer. Br J Cancer (2003) 89:1463-72. doi: 10.1038/sj.bjc.6601243

118. Orsini E, Guarini A, Chiaretti S, Mauro FR, Foa R. The Circulating Dendritic Cell Compartment in Patients With Chronic Lymphocytic Leukemia is Severely Defective and Unable to Stimulate an Effective T-Cell Response. Cancer Res (2003) 63:4497-506.

119. Ormandy LA, Färber A, Cantz T, Petrykowska S, Wedemeyer H, Hörning M, et al. Direct Ex Vivo Analysis of Dendritic Cells in Patients With Hepatocellular Carcinoma. World J Gastroenterol (2006) 12:3275-82. doi: $10.3748 /$ wjg.v12.i20.3275

120. Clavijo-Salomon MA, Ramos RN, Crippa A, Pizzo CR, Bergami-Santos PC, Barbuto JAM. Monocyte-Derived Dendritic Cells Reflect the Immune Functional Status of a Chromophobe Renal Cell Carcinoma Patient: Could it be a General Phenomenon? Cancer Immunol Immunother (2015) 64:16171. doi: 10.1007/s00262-014-1625-9

121. Sakakura K, Chikamatsu K, Takahashi K, Whiteside TL, Furuya N. Maturation of Circulating Dendritic Cells and Imbalance of T-Cell Subsets in Patients With Squamous Cell Carcinoma of the Head and Neck. Cancer Immunol Immunother (2006) 55:151-9. doi: 10.1007/s00262-005-0697-y

122. Aalamian M, Pirtskhalaishvili G, Nunez A, Esche C, Shurin GV, Huland E, et al. Human Prostate Cancer Regulates Generation and Maturation of Monocyte-Derived Dendritic Cells. Prostate (2001) 46:68-75. doi: 10.1002/ 1097-0045(200101)46:1<68::AID-PROS1010>3.0.CO;2-2

123. Binnewies M, Mujal AM, Pollack JL, Combes AJ, Hardison EA, Barry KC, et al. Unleashing Type-2 Dendritic Cells to Drive Protective Antitumor CD4+ T Cell Immunity. Cell (2019) 177:556-71.e16. doi: 10.1016/ j.cell.2019.02.005

124. Cui G, Goll R, Olsen T, Steigen SE, Husebekk A, Vonen B, et al. Reduced Expression of Microenvironmental Th1 Cytokines Accompanies AdenomasCarcinomas Sequence of Colorectum. Cancer Immunol Immunother (2007) 56:985-95. doi: 10.1007/s00262-006-0259-y

125. Perrot I, Blanchard D, Freymond N, Isaac S, Guibert B, Pachéco Y, et al. Dendritic Cells Infiltrating Human Non-Small Cell Lung Cancer Are Blocked at Immature Stage. J Immunol (2007) 178:2763-9. doi: 10.4049/ jimmunol.178.5.2763

126. Toniolo PA, Liu S, Yeh JE, Ye DQ, Barbuto JAM, Frank DA. Deregulation of SOCS5 Suppresses Dendritic Cell Function in Chronic Lymphocytic Leukemia. Oncotarget (2016) 7:46301-14. doi: 10.18632/oncotarget.10093

127. Brown S, Hutchinson CV, Aspinall-O'Dea M, Whetton AD, Johnson SM, Rees-Unwin K, et al. Monocyte-Derived Dendritic Cells From Chronic Myeloid Leukaemia Have Abnormal Maturation and Cytoskeletal Function That is Associated With Defective Localisation and Signalling by Normal ABL1 Protein. Eur J Haematol (2014) 93:96-102. doi: 10.1111/ ejh.12306

128. Lopes AMM, Michelin MA, Murta EFC. Monocyte-Derived Dendritic Cells From Patients With Cervical Intraepithelial Lesions. Oncol Lett (2017) 13:1456-62. doi: 10.3892/ol.2017.5595

129. Shurin GV, Ma Y, Shurin MR. Immunosuppressive Mechanisms of Regulatory Dendritic Cells in Cancer. Cancer Microenviron (2013) 6:15967. doi: 10.1007/s12307-013-0133-3

130. Hwu P, Du MX, Lapointe R, Do M, Taylor MW, Young HA. Indoleamine 2,3-Dioxygenase Production by Human Dendritic Cells Results in the Inhibition of T Cell Proliferation. J Immunol (2000) 164:3596-9. doi: 10.4049/jimmunol.164.7.3596

131. Jonuleit H, Schmitt E, Schuler G, Knop J, Enk AH. Induction of Interleukin 10-Producing, Nonproliferating Cd4+ T Cells With Regulatory Properties by Repetitive Stimulation With Allogeneic Immature Human Dendritic Cells. J Exp Med (2000) 192:1213-22. doi: 10.1084/jem.192.9.1213

132. Kubsch S, Graulich E, Knop J, Steinbrink K. Suppressor Activity of Anergic T Cells Induced by IL-10-Treated Human Dendritic Cells: Association With IL-2- and CTLA-4-Dependent G1 Arrest of the Cell Cycle Regulated by p27Kip1. Eur J Immunol (2003) 33:1988-97. doi: 10.1002/eji.200323600

133. Kuang D-M, Zhao Q, Xu J, Yun J-P, Wu C, Zheng L. Tumor-Educated Tolerogenic Dendritic Cells Induce Cd3e Down-Regulation and Apoptosis of T Cells Through Oxygen-Dependent Pathways. J Immunol (2008) 181:3089-98. doi: 10.4049/jimmunol.181.5.3089

134. Norian LA, Rodriguez PC, O'Mara LA, Zabaleta J, Ochoa AC, Cella M, et al. Tumor-Infiltrating Regulatory Dendritic Cells Inhibit CD8+ T Cell Function via L-Arginine Metabolism. Cancer Res (2009) 69:3086-94. doi: 10.1158/ 0008-5472.CAN-08-2826

135. Bracho-Sanchez E, Hassanzadeh A, Brusko MA, Wallet MA, Keselowsky BG. Dendritic Cells Treated With Exogenous Indoleamine 2,3-Dioxygenase Maintain an Immature Phenotype and Suppress Antigen-Specific T Cell Proliferation. J Immunol Regener Med (2019) 5:100015. doi: 10.1016/ j.regen.2019.100015

136. Ramos RN, Chin LS, dos Santos APSA, Bergami-Santos PC, Laginha F, Barbuto JAM. Monocyte-Derived Dendritic Cells From Breast Cancer Patients Are Biased to Induce CD4+CD25+Foxp3+ Regulatory T Cells. J Leukoc Biol (2012) 92:673-82. doi: 10.1189/jlb.0112048

137. Ghiringhelli F, Puig PE, Roux S, Parcellier A, Schmitt E, Solary E, et al. Tumor Cells Convert Immature Myeloid Dendritic Cells Into TGF- $\beta$ Secreting Cells Inducing CD4 +CD25 + Regulatory T Cell Proliferation. J Exp Med (2005) 202:919-29. doi: 10.1084/jem.20050463

138. Zhong M, Zhong C, Cui W, Wang G, Zheng G, Li L, et al. Induction of Tolerogenic Dendritic Cells by Activated TGF- $\beta /$ Akt/Smad2 Signaling in 
RIG-I-Deficient Stemness-High Human Liver Cancer Cells. BMC Cancer (2019) 19:439. doi: 10.1186/s12885-019-5670-9

139. Demoulin S, Herfs M, Delvenne P, Hubert P. Tumor Microenvironment Converts Plasmacytoid Dendritic Cells Into Immunosuppressive/ Tolerogenic Cells: Insight Into the Molecular Mechanisms. J Leukoc Biol (2013) 93:343-52. doi: 10.1189/jlb.0812397

140. McCarter MD, Baumgartner J, Escobar GA, Richter D, Lewis K, Robinson $\mathrm{W}$, et al. Immunosuppressive Dendritic and Regulatory $\mathrm{T}$ Cells Are Upregulated in Melanoma Patients. Ann Surg Oncol (2007) 14:2854-60. doi: 10.1245/s10434-007-9488-3

141. Harimoto H, Shimizu M, Nakagawa Y, Nakatsuka K, Wakabayashi A, Sakamoto C, et al. Inactivation of Tumor-Specific CD8+CTLs by TumorInfiltrating Tolerogenic Dendritic Cells. Immunol Cell Biol (2013) 91:545-55. doi: $10.1038 /$ icb.2013.38

142. Conrad C, Gregorio J, Wang YH, Ito T, Meller S, Hanabuchi S, et al. Plasmacytoid Dendritic Cells Promote Immunosuppression in Ovarian Cancer via ICOS Costimulation of Foxp3+ T-Regulatory Cells. Cancer Res (2012) 72:5240-9. doi: 10.1158/0008-5472.CAN-12-2271

143. Scarlett UK, Rutkowski MR, Rauwerdink AM, Fields J, Escovar-Fadul X, Baird J, et al. Ovarian Cancer Progression is Controlled by Phenotypic Changes in Dendritic Cells. J Exp Med (2012) 209:495-506. doi: 10.1084/ jem.20111413

144. Papaspyridonos M, Matei I, Huang Y, do Rosario Andre M, Brazier-Mitouart H, Waite JC, et al. Id1 Suppresses Anti-Tumour Immune Responses and Promotes Tumour Progression by Impairing Myeloid Cell Maturation. Nat Commun (2015) 6:6840. doi: 10.1038/ncomms7840

145. Mastelic-Gavillet B, Sarivalasis A, Lozano LE, Wyss T, Inoges S, de Vries IJM, et al. Quantitative and Qualitative Impairments in Dendritic Cell Subsets of Patients With Ovarian or Prostate Cancer. Eur J Cancer (2020) 135:173-82. doi: 10.1016/j.ejca.2020.04.036

146. Yamamoto T, Yanagimoto H, Satoi S, Toyokawa H, Yamao J, Kim S, et al. Circulating Myeloid Dendritic Cells as Prognostic Factors in Patients With Pancreatic Cancer Who Have Undergone Surgical Resection. J Surg Res (2012) 173:299-308. doi: 10.1016/j.jss.2010.09.027

147. Lin A, Schildknecht A, Nguyen LT, Ohashi PS. Dendritic Cells Integrate Signals From the Tumor Microenvironment to Modulate Immunity and Tumor Growth. Immunol Lett (2010) 127:77-84. doi: 10.1016/j.imlet.2009.09.003

148. Fridman WH, Galon J, Pagès F, Tartour E, Sautès-Fridman C, Kroemer G. Prognostic and Predictive Impact of Intra- and Peritumoral Immune Infiltrates. Cancer Res (2011) 71:5601-5. doi: 10.1158/0008-5472.CAN-111316

149. Ambe K, Mori M. Enjoji M. S-100 Protein-Positive Dendritic Cells in Colorectal Adenocarcinomas. Distribution and Relation to the Clinical Prognosis. Cancer (1989) 63:496-503. doi: 10.1002/1097-0142(19890201) 63:3<496::AID-CNCR2820630318>3.0.CO;2-K

150. Nakayama Y, Inoue Y, Minagawa N, Katsuki T, Nagashima N, Onitsuka K, et al. Relationships Between S-100 Protein-Positive Cells and Clinicopathological Factors in Patients With Colorectal Cancer. Anticancer Res (2003) 23:4423-6.

151. Dadabayev AR, Sandel MH, Menon AG, Morreau H, Melief CJM, Offringa R, et al. Dendritic Cells in Colorectal Cancer Correlate With Other TumorInfiltrating Immune Cells. Cancer Immunol Immunother (2004) 53:978-86. doi: 10.1007/s00262-004-0548-2

152. Nagorsen D, Voigt S, Berg E, Stein H, Thiel E, Loddenkemper C. TumorInfiltrating Macrophages and Dendritic Cells in Human Colorectal Cancer: Relation to Local Regulatory T Cells, Systemic T-Cell Response Against Tumor-Associated Antigens and Survival. J Transl Med (2007) 5:62. doi: 10.1186/1479-5876-5-62

153. Kusume A, Sasahira T, Luo Y, Isobe M, Nakagawa N, Tatsumoto N, et al. Suppression of Dendritic Cells by HMGB1 is Associated With Lymph Node Metastasis of Human Colon Cancer. Pathobiology (2009) 76:155-62. doi: $10.1159 / 000218331$

154. Gai X-D, Li C, Song Y, Lei Y-M, Yang B-X. In Situ Analysis of FOXP3+ Regulatory T Cells and Myeloid Dendritic Cells in Human Colorectal Cancer Tissue and Tumor-Draining Lymph Node. BioMed Rep (2013) 1:207-12. doi: $10.3892 /$ br.2012.35

155. Gai XD, Song Y, Li C, Lei YM, Yang B. Potential Role of Plasmacytoid Dendritic Cells for FOXP3+ Regulatory T Cell Development in Human
Colorectal Cancer and Tumor Draining Lymph Node. Pathol Res Pract (2013) 209:774-8. doi: 10.1016/j.prp.2013.08.011

156. Kießler M, Plesca I, Sommer U, Wehner R, Wilczkowski F, Müller L, et al. Tumor-Infiltrating Plasmacytoid Dendritic Cells Are Associated With Survival in Human Colon Cancer. J Immunother Cancer (2021) 9:1813. doi: 10.1136/jitc-2020-001813

157. Wu J, Cheng H, Wang H, Zang G, Qi L, Lv X, et al. Correlation Between Immune Lymphoid Cells and Plasmacytoid Dendritic Cells in Human Colon Cancer. Front Immunol (2021) 12:601611. doi: 10.3389/fimmu.2021.601611

158. Schwaab T, Weiss JE, Schned AR, Barth J. Dendritic Cell Infiltration in Colon Cancer. J Immunother (2001) 24:130-7. doi: 10.1097/00002371200103000-00007

159. Suzuki A, Masuda A, Nagata H, Kameoka S, Kikawada Y, Yamakawa M, et al. Mature Dendritic Cells Make Clusters With T Cells in the Invasive Margin of Colorectal Carcinoma. J Pathol (2002) 196:37-43. doi: 10.1002/ path.1018

160. Gulubova M, Manolova I, Cirovski G, Sivrev D. Recruitment of Dendritic Cells in Human Liver With Metastases. Clin Exp Metastasis (2008) 25:77785. doi: 10.1007/s10585-008-9191-1

161. Cui G, Yuan A, Goll R, Olsen T, Husebekk A, Vonen B, et al. Distinct Changes of Dendritic Cell Number and IL-12 mRNA Level in Adjacent Mucosa Throughout the Colorectal Adenoma-Carcinoma Sequence. Cancer Immunol Immunother (2007) 56:1993-2001. doi: 10.1007/s00262-007-0345-9

162. Yuan A, Steigen SE, Goll R, Vonen B, Husbekk A, Cui G, et al. Dendritic Cell Infiltration Pattern Along the Colorectal Adenoma-Carcinoma Sequence. APMIS (2008) 116:445-56. doi: 10.1111/j.1600-0463.2008.00879.x

163. Bauer K, Michel S, Reuschenbach M, Nelius N, Von Knebel Doeberitz M, Kloor M. Dendritic Cell and Macrophage Infiltration in MicrosatelliteUnstable and Microsatellite-Stable Colorectal Cancer. Familial Cancer (Fam Cancer) (2011) 10:557-65. doi: 10.1007/s10689-011-9449-7

164. Banerjea A, Ahmed S, Hands RE, Huang F, Han X, Shaw PM, et al. Colorectal Cancers With Microsatellite Instability Display mRNA Expression Signatures Characteristic of Increased Immunogenicity. Mol Cancer (2004) 3:1-11. doi: 10.1186/1476-4598-3-21

165. Miyagawa S, Soeda J, Takagi S, Miwa S, Ichikawa E, Noike T. Prognostic Significance of Mature Dendritic Cells and Factors Associated With Their Accumulation in Metastatic Liver Tumors From Colorectal Cancer. Hum Pathol (2004) 35:1392-6. doi: 10.1016/j.humpath.2004.07.018

166. Inoue $\mathrm{Y}$, Nakayama $\mathrm{Y}$, Minagawa N, Katsuki T, Nagashima N, Matsumoto $\mathrm{K}$, et al. Relationship Between Interleukin-12-Expressing Cells and AntigenPresenting Cells in Patients With Colorectal Cancer. Anticancer Res (2005) 25:3541-6

167. Gulubova M, Manolova I, Ananiev J, Kjurkchiev D, Julianov A, Altunkova I. Relationship of TGF- $\beta 1$ and Smad7 Expression With Decreased Dendritic Cell Infiltration in Liver Gastrointestinal Cancer Metastasis. Apmis (2013) 121:967-75. doi: 10.1111/apm.12096

168. Kocián P, Šedivcová M, Drgáč J, Černá K, Hoch J, Kodet R, et al. TumorInfiltrating Lymphocytes and Dendritic Cells in Human Colorectal Cancer: Their Relationship to KRAS Mutational Status and Disease Recurrence. Hum Immunol (2011) 72:1022-8. doi: 10.1016/j.humimm.2011.07.312

169. Gulubova MV, Ananiev JR, Vlaykova TI, Yovchev Y, Tsoneva V, Manolova IM. Role of Dendritic Cells in Progression and Clinical Outcome of Colon Cancer. Int J Colorectal Dis (2012) 27:159-69. doi: 10.1007/s00384-011-1334-1

170. Li M, Wang H, Li W, Peng Y, Xu F, Shang J, et al. Identification and Validation of an Immune Prognostic Signature in Colorectal Cancer. Int Immunopharmacol (2020) 88:106868. doi: 10.1016/j.intimp.2020.106868

171. Li E, Yang X, Du Y, Wang G, Chan DW, Wu D, et al. CXCL8 Associated Dendritic Cell Activation Marker Expression and Recruitment as Indicators of Favorable Outcomes in Colorectal Cancer. Front Immunol (2021) 12:667177. doi: 10.3389/fimmu.2021.667177

172. Sandel MH, Dadabayev AR, Menon AG, Morreau H, Melief CJM, Offringa R, et al. Prognostic Value of Tumor-Infiltrating Dendritic Cells in Colorectal Cancer: Role of Maturation Status and Intratumoral Localization. Clin Cancer Res (2005) 11:2576-82. doi: 10.1158/1078-0432.CCR-04-1448

173. Pryczynicz A, Cepowicz D, Zaręba K, Gryko M, Hołody-Zaręba J, Kędra B, et al. Dysfunctions in the Mature Dendritic Cells Are Associated With the Presence of Metastases of Colorectal Cancer in the Surrounding Lymph Nodes. Gastroenterol Res Pract (2016) 2016:1-5. doi: 10.1155/2016/2405437 
174. Miller TJ, Anyaegbu CC, Lee-Pullen TF, Spalding LJ, Platell CF, McCoy MJ. PD-L1+ Dendritic Cells in the Tumor Microenvironment Correlate With Good Prognosis and CD8+ T Cell Infiltration in Colon Cancer. Cancer Sci (2021) 112:1173-83. doi: 10.1111/cas.14781

175. Huang A, Gilmour JW, Imami N, Amjadi P, Henderson DC, Allen-Mersh TG. Increased Serum Transforming Growth Factor- $\beta 1$ in Human Colorectal Cancer Correlates With Reduced Circulating Dendritic Cells and Increased Colonic Langerhans Cell Infiltration. Clin Exp Immunol (2003) 134:270-8. doi: 10.1046/j.1365-2249.2003.02295.x

176. Della Porta M, Danova M, Rigolin GM, Brugnatelli S, Rovati B, Tronconi C, et al. Dendritic Cells and Vascular Endothelial Growth Factor in Colorectal Cancer: Correlations With Clinicobiological Findings. Oncology (2005) 68:276-84. doi: 10.1159/000086784

177. Bellik L, Gerlini G, Parenti A, Ledda F, Pimpinelli N, Neri B, et al. Role of Conventional Treatments on Circulating and Monocyte-Derived Dendritic Cells in Colorectal Cancer. Clin Immunol (2006) 121:74-80. doi: 10.1016/ j.clim.2006.06.011

178. Orsini G, Legitimo A, Failli A, Ferrari P, Nicolini A, Spisni R, et al. Quantification of Blood Dendritic Cells in Colorectal Cancer Patients During the Course of Disease. Pathol Oncol Res (2014) 20:267-76. doi: 10.1007/s12253-013-9691-4

179. Osada T, Chong G, Tansik R, Hong T, Spector N, Kumar R, et al. The Effect of Anti-VEGF Therapy on Immature Myeloid Cell and Dendritic Cells in Cancer Patients. Cancer Immunol Immunother (2008) 57:1115-24. doi: $10.1007 / \mathrm{s} 00262-007-0441-\mathrm{x}$

180. Orsini G, Legitimo A, Failli A, Ferrari P, Nicolini A, Spisni R, et al. Defective Generation and Maturation of Dendritic Cells From Monocytes in Colorectal Cancer Patients During the Course of Disease. Int J Mol Sci (2013) 14:22022-41. doi: 10.3390/ijms141122022

181. Maciejewski R, Radej S, Furmaga J, Chrościcki A, Rudzki S, Roliński J, et al. Evaluation of Immature Monocyte-Derived Dendritic Cels Generated From Patients With Colorectal Cancer. Pol Prz Chir Polish J Surg (2013) 85:714-20. doi: 10.2478/pjs-2013-0109

182. Hsu YL, Chen YJ, Chang WA, Jian SF, Fan HL, Wang JY, et al. Interaction Between Tumor-Associated Dendritic Cells and Colon Cancer Cells Contributes to Tumor Progression via CXCL1. Int J Mol Sci (2018) 19:2427. doi: 10.3390/ijms19082427

183. Xia C, Braunstein Z, Toomey AC, Zhong J, Rao X. S100 Proteins as an Important Regulator of Macrophage Inflammation. Front Immunol (2018) 8:1908. doi: $10.3389 /$ fimmu. 2017.01908

184. Michielsen AJ, Hogan AE, Marry J, Tosetto M, Cox F, Hyland JM, et al. Tumour Tissue Microenvironment Can Inhibit Dendritic Cell Maturation in Colorectal Cancer. PLoS One (2011) 6:e27944. doi: 10.1371/ journal.pone.0027944

185. Michielsen AJ, O’Sullivan JN, Ryan EJ. Tumor Conditioned Media From Colorectal Cancer Patients Inhibits Dendritic Cell Maturation. Oncoimmunology (2012) 1:751-3. doi: 10.4161/onci.19570

186. Michielsen AJ, Noonan S, Martin P, Tosetto M, Marry J, Biniecka M, et al. Inhibition of Dendritic Cell Maturation by the Tumor Microenvironment Correlates With the Survival of Colorectal Cancer Patients Following Bevacizumab Treatment. Mol Cancer Ther (2012) 11:1829-37. doi: 10.1158/1535-7163.MCT-12-0162

187. Morrissey ME, Byrne R, Nulty C, McCabe NH, Lynam-Lennon N, Butler CT, et al. The Tumour Microenvironment of the Upper and Lower Gastrointestinal Tract Differentially Influences Dendritic Cell Maturation. BMC Cancer (2020) 20:1-13. doi: 10.1186/s12885-020-07012-y

188. Topalian SL, Drake CG, Pardoll DM. Immune Checkpoint Blockade: A Common Denominator Approach to Cancer Therapy. Cancer Cell (2015) 27:450-61. doi: 10.1016/j.ccell.2015.03.001

189. Van Den Bulk J, Verdegaal EME, Ruano D, Ijsselsteijn ME, Visser M, van der Breggen R, et al. Neoantigen-Specific Immunity in Low Mutation Burden Colorectal Cancers of the Consensus Molecular Subtype 4. Genome Med (2019) 11:87. doi: 10.1186/s13073-019-0697-8

190. Yost KE, Satpathy AT, Wells DK, Qi Y, Wang C, Kageyama R, et al. Clonal Replacement of Tumor-Specific T Cells Following PD-1 Blockade. Nat Med (2019) 25:1251-9. doi: 10.1038/s41591-019-0522-3

191. Sánchez-Paulete AR, Cueto FJ, Martínez-López M, Labiano S, MoralesKastresana A, Rodríguez-Ruiz ME, et al. Cancer Immunotherapy With
Immunomodulatory Anti-CD137 and Anti-PD-1 Monoclonal Antibodies Requires BATF3-Dependent Dendritic Cells. Cancer Discovery (2016) 6:719. doi: 10.1158/2159-8290.CD-15-0510

192. Garris CS, Arlauckas SP, Kohler RH, Trefny MP, Garren S, Piot C, et al. Successful Anti-PD-1 Cancer Immunotherapy Requires T Cell-Dendritic Cell Crosstalk Involving the Cytokines IFN- $\gamma$ and IL-12. Immunity (2018) 49:1148-61.e7. doi: 10.1016/j.immuni.2018.09.024

193. Spranger S, Dai D, Horton B, Gajewski TF. Tumor-Residing Batf3 Dendritic Cells Are Required for Effector T Cell Trafficking and Adoptive T Cell Therapy. Cancer Cell (2017) 31:711-23.e4. doi: 10.1016/J.CCELL.2017.04.003

194. Diao J, Gu H, Tang M, Zhao J, Cattral MS. Tumor Dendritic Cells (DCs) Derived From Precursors of Conventional DCs Are Dispensable for Intratumor CTL Responses. J Immunol (2018) 201:1306-14. doi: 10.4049/ jimmunol.1701514

195. Chow MT, Ozga AJ, Servis RL, Frederick DT, Lo JA, Fisher DE, et al. Intratumoral Activity of the CXCR3 Chemokine System Is Required for the Efficacy of Anti-PD-1 Therapy. Immunity (2019) 50:1498-512.e5. doi: 10.1016/j.immuni.2019.04.010

196. Salmon H, Idoyaga J, Rahman A, Leboeuf M, Remark R, Jordan S, et al. Expansion and Activation of CD103 + Dendritic Cell Progenitors at the Tumor Site Enhances Tumor Responses to Therapeutic PD-L1 and BRAF Inhibition. Immunity (2016) 44:924-38. doi: 10.1016/j.immuni.2016.03.012

197. Huang T-X, Tan X-Y, Huang H-S, Li Y-T, Liu B-L, Liu K-S, et al. Targeting Cancer-Associated Fibroblast-Secreted WNT2 Restores Dendritic CellMediated Antitumour Immunity. Gut (2021) 70:1-12. doi: 10.1136/gutjnl2020-322924

198. Kather JN, Halama N. Harnessing the Innate Immune System and Local Immunological Microenvironment to Treat Colorectal Cancer. Br J Cancer (2019) 120:871-82. doi: 10.1038/s41416-019-0441-6

199. Murgaski A, Bardet PMR, Arnouk SM, Clappaert EJ, Laoui D. Unleashing Tumour-Dendritic Cells to Fight Cancer by Tackling Their Three A's: Abundance, Activation and Antigen-Delivery. Cancers (Basel) (2019) 11:670. doi: 10.3390/cancers11050670

200. Lee SC, Srivastava RM, López-Albaitero A, Ferrone S, Ferris RL. Natural Killer (NK):dendritic Cell (DC) Cross Talk Induced by Therapeutic Monoclonal Antibody Triggers Tumor Antigen-Specific T Cell Immunity. Immunol Res (2011) 50:248-54. doi: 10.1007/s12026-011-8231-0

201. Barry KC, Hsu J, Broz ML, Cueto FJ, Binnewies M, Combes AJ, et al. A Natural Killer-Dendritic Cell Axis Defines Checkpoint Therapy-Responsive Tumor Microenvironments. Nat Med (2018) 24:1178-91. doi: 10.1038/ s41591-018-0085-8

202. Pampena MB, Levy EM. Natural Killer Cells as Helper Cells in Dendritic Cell Cancer Vaccines. Front Immunol (2015) 6:13. doi: 10.3389/fimmu.2015.00013

203. Bouwer AL, Saunderson SC, Caldwell FJ, Damani TT, Pelham SJ, Dunn AC, et al. NK Cells Are Required for Dendritic Cell-Based Immunotherapy at the Time of Tumor Challenge. J Immunol (2014) 192:2514-21. doi: 10.4049/ jimmunol.1202797

204. Karimi K, Boudreau JE, Fraser K, Liu H, Delanghe J, Gauldie J, et al. Enhanced Antitumor Immunity Elicited by Dendritic Cell Vaccines is a Result of Their Ability to Engage Both CTL and Ifn $\gamma$-Producing NK Cells. Mol Ther (2008) 16:411-8. doi: 10.1038/sj.mt.6300347

205. Saxena M, Bhardwaj N. Re-Emergence of Dendritic Cell Vaccines for Cancer Treatment. Trends Cancer (2018) 4:119-37. doi: 10.1016/j.trecan.2017.12.007

206. Lu L, Yan H, Shyam-Sundar V, Janowitz T. Cross-Sectional and Longitudinal Analysis of Cancer Vaccination Trials Registered on the US Clinical Trials Database Demonstrates Paucity of Immunological Trial Endpoints and Decline in Registration Since 2008. Drug Des Devel Ther (2014) 8:1539-53. doi: 10.2147/DDDT.S65963

207. Constantino J, Gomes C, Falcão A, Cruz MT, Neves BM. Antitumor Dendritic Cell-Based Vaccines: Lessons From 20 Years of Clinical Trials and Future Perspectives. Transl Res (2016) 168:74-95. doi: 10.1016/ j.trsl.2015.07.008

208. Lesterhuis WJ, de Vries IJM, Schuurhuis DH, Boullart ACI, Jacobs JFM, de Boer AJ, et al. Vaccination of Colorectal Cancer Patients With CEA-Loaded Dendritic Cells: Antigen-Specific T Cell Responses in DTH Skin Tests. Ann Oncol (2006) 17:974-80. doi: 10.1093/annonc/mdl072

209. Ueda Y, Itoh T, Nukaya I, Kawashima I, Okugawa K, Yano Y, et al. Dendritic Cell-Based Immunotherapy of Cancer With Carcinoembryonic Antigen- 
Derived, HLA-A24-Restricted CTL Epitope: Clinical Outcomes of 18 Patients With Metastatic Gastrointestinal or Lung Adenocarcinomas. Int J Oncol (2004) 24:909-17. doi: 10.3892/ijo.24.4.909

210. Kavanagh B, Ko A, Venook A, Margolin K, Zeh H, Lotze M, et al. Vaccination of Metastatic Colorectal Cancer Patients With Matured Dendritic Cells Loaded With Multiple Major Histocompatibility Complex Class I Peptides. J Immunother (2007) 30:762-72. doi: 10.1097/CJI.0b013e318133451c

211. Barth RJ, Fisher DA, Wallace PK, Channon JY, Noelle RJ, Gui J, et al. A Randomized Trial of Ex Vivo CD40L Activation of a Dendritic Cell Vaccine in Colorectal Cancer Patients: Tumor-Specific Immune Responses Are Associated With Improved Survival. Clin Cancer Res (2010) 16:5548-56. doi: 10.1158/1078-0432.CCR-10-2138

212. Liu Y, Zhang W, Zhang B, Yin X, Pang Y. DC Vaccine Therapy Combined Concurrently With Oral Capecitabine in Metastatic Colorectal Cancer Patients. Hepatogastroenterology (2013) 60:23-7. doi: 10.5754/12522

213. Caballero-Baños M, Benitez-Ribas D, Tabera J, Varea S, Vilana R, Bianchi L, et al. Phase II Randomised Trial of Autologous Tumour Lysate Dendritic Cell Plus Best Supportive Care Compared With Best Supportive Care in PreTreated Advanced Colorectal Cancer Patients. Eur J Cancer (2016) 64:16774. doi: 10.1016/j.ejca.2016.06.008

214. Liu KJ, Chao TY, Chang JY, Cheng AL, Ch'Ang HJ, Kao WY, et al. A Phase I Clinical Study of Immunotherapy for Advanced Colorectal Cancers Using Carcinoembryonic Antigen-Pulsed Dendritic Cells Mixed With Tetanus Toxoid and Subsequent IL-2 Treatment John T Kung. J BioMed Sci (2016) 23:1-11. doi: 10.1186/s12929-016-0279-7

215. Rodriguez J, Castañón E, Perez-Gracia JL, Rodriguez I, Viudez A, Alfaro C, et al. A Randomized Phase II Clinical Trial of Dendritic Cell Vaccination Following Complete Resection of Colon Cancer Liver Metastasis. J Immunother Cancer (2018) 6:1-7. doi: 10.1186/s40425-018-0405-z

216. Snook AE, Baybutt TR, Xiang B, Abraham TS, Flickinger JC, Hyslop T, et al. Split Tolerance Permits Safe Ad5-GUCY2C-PADRE Vaccine-Induced TCell Responses in Colon Cancer Patients. J Immunother Cancer (2019) 7:112. doi: 10.1186/s40425-019-0576-2

217. Kobie JJ, Wu RS, Kurt RA, Lou S, Adelman MK, Whitesell LJ, et al. Transforming Growth Factor $\beta$ Inhibits the Antigen-Presenting Functions and Antitumor Activity of Dendritic Cell Vaccines. Cancer Res (2003) 63:1860-4.

218. Vasaturo A, Di Blasio S, Peeters DGA, de Koning CCH, de Vries JM, Figdor CG, et al. Clinical Implications of Co-Inhibitory Molecule Expression in the Tumor Microenvironment for DC Vaccination: A Game of Stop and Go. Front Immunol (2013) 4:417. doi: 10.3389/fimmu.2013.00417

219. Bakdash G, Buschow SI, Gorris MAJ, Halilovic A, Hato SV, Sköld AE, et al. Expansion of a BDCA1 + CD14 + Myeloid Cell Population in Melanoma Patients May Attenuate the Efficacy of Dendritic Cell Vaccines. Cancer Res (2016) 76:4332-46. doi: 10.1158/0008-5472.CAN-15-1695

220. Saxena M, van der Burg SH, Melief CJM, Bhardwaj N. Therapeutic Cancer Vaccines. Nat Rev Cancer (2021) 21:360-78. doi: 10.1038/s41568-021-00346-0

221. Li H, Yu J, Wu Y, Shao B, Wei X. In Situ Antitumor Vaccination: Targeting the Tumor Microenvironment. J Cell Physiol (2020) 235:5490-500. doi: $10.1002 /$ jcp. 29551

222. Sheen MR, Fiering S. In Situ Vaccination: Harvesting Low Hanging Fruit on the Cancer Immunotherapy Tree. Wiley Interdiscip Rev Nanomed Nanobiotechnol (2019) 11:1-12. doi: 10.1002/wnan.1524
223. Tang T, Huang X, Zhang G, Hong Z, Bai X, Liang T. Advantages of Targeting the Tumor Immune Microenvironment Over Blocking Immune Checkpoint in Cancer Immunotherapy. Signal Transduct Target Ther (2021) 6:72. doi: 10.1038/s41392-020-00449-4

224. Heckelsmiller K, Rall K, Beck S, Schlamp A, Seiderer J, Jahrsdörfer B, et al. Peritumoral CpG DNA Elicits a Coordinated Response of CD8 T Cells and Innate Effectors to Cure Established Tumors in a Murine Colon Carcinoma Model. J Immunol (2002) 169:3892-9. doi: 10.4049/jimmunol.169.7.3892

225. Braunstein MJ, Kucharczyk J, Adams S. Targeting Toll-Like Receptors for Cancer Therapy. Target Oncol (2018) 13:583-98. doi: 10.1007/s11523-0180589-7

226. Kerr WG, Chisholm JD. The Next Generation of Immunotherapy for Cancer: Small Molecules Could Make Big Waves. J Immunol (2019) 202:11-9. doi: 10.4049/jimmunol.1800991

227. Schmoll HJ, Wittig B, Arnold D, Riera-Knorrenschild J, Nitsche D, Kroening $\mathrm{H}$, et al. Maintenance Treatment With the Immunomodulator MGN1703, a Toll-Like Receptor 9 (TLR9) Agonist, in Patients With Metastatic Colorectal Carcinoma and Disease Control After Chemotherapy: A Randomised, Double-Blind, Placebo-Controlled Trial. J Cancer Res Clin Oncol (2014) 140:1615-24. doi: 10.1007/s00432-014-1682-7

228. Chon HJ, Kim H, Noh JH, Yang H, Lee WS, Kong SJ, et al. STING Signaling is a Potential Immunotherapeutic Target in Colorectal Cancer. J Cancer (2019) 10:4932-8. doi: 10.7150/jca.32806

229. Kamal Y, Schmit SL, Frost HR, Amos CI. The Tumor Microenvironment of Colorectal Cancer Metastases: Opportunities in Cancer Immunotherapy. Immunotherapy (2020) 12:1083-100. doi: 10.2217/imt-2020-0026

230. Lee JY, Chaudhuri O. Modeling the Tumor Immune Microenvironment for Drug Discovery Using 3D Culture. APL Bioeng (2021) 5:10903. doi: 10.1063/ 5.0030693

231. Yuki K, Cheng N, Nakano M, Kuo CJ. Organoid Models of Tumor Immunology. Trends Immunol (2020) 41:652-64. doi: 10.1016/ j.it.2020.06.010

232. Fiorini E, Veghini L, Corbo V. Modeling Cell Communication in Cancer With Organoids: Making the Complex Simple. Front Cell Dev Biol (2020) 8:166. doi: $10.3389 /$ fcell.2020.00166

Conflict of Interest: The authors declare that the research was conducted in the absence of any commercial or financial relationships that could be construed as a potential conflict of interest.

Publisher's Note: All claims expressed in this article are solely those of the authors and do not necessarily represent those of their affiliated organizations, or those of the publisher, the editors and the reviewers. Any product that may be evaluated in this article, or claim that may be made by its manufacturer, is not guaranteed or endorsed by the publisher.

Copyright $\odot 2021$ Subtil, Cambi, Tauriello and de Vries. This is an open-access article distributed under the terms of the Creative Commons Attribution License (CC BY). The use, distribution or reproduction in other forums is permitted, provided the original author(s) and the copyright owner(s) are credited and that the original publication in this journal is cited, in accordance with accepted academic practice. No use, distribution or reproduction is permitted which does not comply with these terms. 